\title{
REFLEXIONES SOBRE LA APLICACIÓN DEL PRINCIPIO DE RECIPROCIDAD EN LA ORDEN EUROPEA DE DETENCIÓN Y ENTREGA
}

\author{
Leticia Fontestad Portalés*
}

\begin{abstract}
Resumen: En este trabajo de investigación tras una breve exposición acerca de la interpretación que deba hacerse del principio de reciprocidad desde el punto de vista del Derecho internacional como principio básico de las relaciones internacionales entre los Estados, nos planteamos el alcance que al mismo deba darse en las concretas relaciones extradicionales entre los Estados. Tras poner de manifiesto que, en el ámbito de la extradición, como instrumento de cooperación jurídica penal internacional, estamos ante un principio que, tradicionalmente, ha condicionado la entrega de la persona reclamada alcanzando, además, el carácter de principio constitucional, reflexionaremos sobre la posible erradicación del mismo en el procedimiento de la orden europea de detención y entrega o, si, por el contrario, el legislador europeo, una vez más, ha fracasado en el
\end{abstract}

Recibido: agosto 2020. Aceptado: febrero 2021

* Profesora Titular de Derecho Procesal. ORCID: https://orcid.org/00000001-5382-7990. Facultad de Derecho de la Universidad de Málaga. Dirección Bulevar Louis Pasteur, 26. 29071. Email: 1fp@uma.es. 
intento de suprimir de la orden europea de detención y entrega, los principios clásicos de la extradición.

Palabras clave: Principio de reciprocidad. Extradición. Orden europea de detención y entrega. Cooperación judicial internacional. Euroorden.

\begin{abstract}
This is a research work, in which after making a brief presentation about the interpretation that should be made of the principle of reciprocity from the point of view of international law as the basic principle of international relations between States, we consider the scope that must be given in the specific extraditional relations between the States. After showing that in the field of extradition, as an instrument of international criminal legal cooperation, we are faced with a principle that traditionally has conditioned the surrender of the person sought, also reaching the character of a constitutional principle, we consider its possible eradication in the procedure of the European arrest warrant and surrender or, if, on the contrary, the European legislator has once again failed in the attempt to remove from the European arrest warrant and surrender, the classical principles of extradition.
\end{abstract}

Keywords: Principle of reciprocity. Extradition. European arrest and surrender. International Judicial Cooperation. Eurowarrant.

\title{
1. Introducción
}

Este trabajo de investigación ${ }^{1}$ surgió como un breve comentario al principio de reciprocidad como principio básico en el Derecho internacional para, posteriormente, dar unas breves explicaciones acerca de su categorización como principio constitucional en relación a su aplicación en el procedimiento penal de extradición. Es por ello por lo que no

1 Esta contribución científica se realiza en el marco del Programa de ayudas a Proyectos de $\mathrm{I}+\mathrm{D}+\mathrm{i}$ para universidades y entidades públicas de investigación del Sistema Andaluz del Conocimiento, en el ámbito del Plan Andaluz de Investigación, Desarrollo e Innovación (PAIDI 2020) "El uso de las TICs en la Cooperación Jurídica Penal Internacional: Construyendo la Sociedad Digital Andaluza del Futuro" (PY18-1059), siendo la Dra. FONTESTAD PORTALÉS Investigadora Principal. 
analizamos en profundidad el principio de reciprocidad en general, ni llevamos a cabo tampoco un exhaustivo estudio de la extradición, ni de la orden europea de detención y entrega, como instrumentos de cooperación judicial internacional.

Tras un sintético análisis acerca del origen y del funcionamiento del principio de reciprocidad con carácter general, y desde el punto de vista del Derecho internacional, dedicamos nuestra atención a la reciprocidad como axioma de la cooperación judicial penal internacional.

En nuestro estudio acerca de la aplicación del principio de reciprocidad en el procedimiento de la extradición partimos de un principio que adquiere la categoría de principio constitucional pues, como es del conocimiento de todos, es la propia Constitución española la que, en su artículo $13.3^{2}$, exige el cumplimiento de la reciprocidad como condición para poder proceder a la extradición de la persona reclamada por el Estado requirente. Este principio de legalidad extradicional, como lo ha venido a denominar la doctrina ${ }^{3}$, supone, además, una garantía reconocida en nuestra Ley de extradición Pasiva ${ }^{4}$, en adelante, LEP.

Que la reciprocidad es un principio de carácter constitucional que informa el procedimiento de extradición no plantea excesivos problemas excepto, quizás, en el alcance y

2 "La extradición sólo se concederá en cumplimiento de un tratado o de la ley, atendiendo al principio de reciprocidad. Quedan excluidos de la extradición los delitos políticos, no considerándose como tales los actos de terrorismo".

3 Vid. por todos DE LA QUADRA-SALCEDO JANINI, T., "La orden europea de detención y entrega y el principio constitucional de reciprocidad”, en Revista española de derecho europeo, núm. 18, 2006, pág. 11 (versión electrónica, disponible en BIB 2006/806) y SÁNCHEZ LEGIDO, A., "La euro-orden, el principio de doble incriminación y la garantía de los Derechos fundamentales", en Revista electrónica de estudios internacionales (REEI), núm. 14 (2007).

4 Ley 4/1985, de 21 de marzo, de Extradición Pasiva (BOE núm. 73, de 26 de marzo de 1985). 
contenido que deba darse al mismo. Esto es así porque que son múltiples y variadas las interpretaciones que podemos encontrar acerca de esta cuestión, fundamentalmente como afirma el Tribunal Constitucional, en lo que se refiere al grado de exigencia de la reciprocidad entre los distintos Estados.

Aun cuando está plenamente aceptada la exigencia de este principio constitucional en el procedimiento de la extradición nos atrevemos a poner de manifiesto que es un principio que se encuentra en declive, siendo así que no son pocos los ordenamientos jurídicos que, en materia de cooperación jurídica internacional, suprimen este principio de reciprocidad $^{5}$. En este sentido, el artículo 277 de la Ley Orgánica del Poder Judicial ${ }^{6}$, ha suprimido la exigencia de la reciprocidad tras la reforma operada en el año 2015 en materia de cooperación jurisdiccional ${ }^{7}$. En el mismo sentido, la Ley sobre cooperación jurídica internacional en el ámbito civil ${ }^{8}$, en adelante LCJI, cuando regula el principio general favorable de cooperación $n^{9}$, en su artículo 3 , también parte de la no exigencia de reciprocidad entre los Estados.

5 AA.VV., "Una propuesta de Ley de cooperación jurídica internacional en materia civil", Boletín del Ministerio de Justicia, Año LXVI, núm. 2143, junio 2012, pág. 10. En relación a la ausencia de reciprocidad en materia de cooperación en Italia Vid. IVO MALVEZZI, M., "Reconocimiento de sentencias Extranjeras: Los procedimientos del derecho interno italiano y español", en Anales de derecho, Universidad de Murcia, Número 23, 2005, pág. 346.

6 "Los Juzgados y Tribunales españoles prestarán a las autoridades judiciales extranjeras la cooperación que les soliciten para el desempeño de su función jurisdiccional, de conformidad con lo establecido en los tratados y convenios internacionales en los que España sea parte, las normas de la Unión Europea y las leyes españolas sobre esta materia".

7 Ley Orgánica 7/2015, de 21 de julio, por la que se modifica la Ley Orgánica 6/1985, de 1 de julio, del Poder Judicial (BOE núm. 174, de 22 de julio de 2015).

8 Ley 29/2015, de 30 de julio, de cooperación jurídica internacional en materia civil (BOE núm. 182, de 31 de julio de 2015).

9 Sobre el principio general favorable de cooperación y su alcance puede consultarse la obra de FONT I SEGURA, A., "Artículo 3. principio 
Aun cuando la extradición no supone el objetivo fundamental de nuestro trabajo, no dejaremos de hacer una breve referencia a la incidencia del incumplimiento de este principio de reciprocidad en el ámbito del procedimiento de la extradición poniéndolo en relación con una posible vulneración de los derechos fundamentales reconocidos en nuestra Constitución.

Para finalizar, reflexionamos sobre la controvertida aplicación del principio de reciprocidad, o principio de legalidad extradicional, en el procedimiento de la orden europea de detención y entrega en el ámbito de la Unión Europea.

Partiendo de la opinión doctrinal mayoritaria ${ }^{10}$, según la cual la orden europea de detención y entrega que sustituye a la extradición entre los países miembros de la Unión Europea, es una extradición simplificada y, por tanto, podríamos incluirla en un concepto amplio de extradición a pesar de las importantes diferencias que existen entre ambos instrumentos de cooperación judicial internacional ${ }^{11}$, la respuesta

general favorable de cooperación", Comentarios a la ley de cooperación jurídica internacional en materia civil, MÉNDEZ GONZÁLEZ, F.P., y PALAO MORENO, G., (dirs.), Ed. Tirant lo Blanch, Valencia 2017, pp. 43-54.

10 CONDE-PUMPIDO TOURÓN, C., "La orden de detención europea”, Actas del I Congreso Internacional. El espacio Judicial Europeo, celebrado en Toledo del 29 al 31 de octubre de 2003, pp. 8-10; BUENO ARÚS, F. y DE MIGUEL ZARAGOZA, J., Manual de Derecho Penal Internacional, Universidad Pontificia de Comillas, Madrid 2003, pág. 236 y DE MIGUEL ZARAGOZA, J., "Algunas consideraciones sobre la Decisión Marco relativa a la orden de detención europea y a los procedimientos de entrega en la perspectiva de la extradición", Actualidad Penal, 2003-1, marginales 140-141 (núm. 4, del 20 al 26 de enero de 2003). GONZÁLEZ-CUELLAR SERRANO, por su parte, afirma que "La euroorden es, pues, una especie de extradición, extremadamente autoritaria y de muy baja calidad técnico-jurídica...”. Cfr. GONZÁLEZCUELLAR SERRANO, N., "La "Euroorden": hacia una Europa de los carceleros", en Diario La Ley núm. 6619, 2006, pág. 2.

11 No podemos dejar de advertir en este momento que son numerosos también los autores que entienden que nos encontramos ante instrumentos 
no deja de ser afirmativa, lo que no supone que ésta sea la conclusión a la que nosotros finalmente lleguemos a la luz de todo lo expuesto. Por lo que, partiendo de esta opinión mayoritaria, analizaremos el posible régimen de aplicación del principio de reciprocidad en el procedimiento de la orden europea de detención y entrega poniendo, sin embargo, de relieve los posibles obstáculos que la exigencia de la garantía de reciprocidad por parte del Estado emisor podría causar en este sistema de entrega europeo. Un primer obstáculo, por ejemplo, podríamos encontrarlo en el hecho de que el control del cumplimiento de la exigencia de reciprocidad es competencia del Gobierno ${ }^{12}$, siendo así que el procedimiento de la orden de detención y entrega no prevé la intervención del Gobierno excepto en lo que se refiere a la intervención del Ministerio de Justicia como autoridad central ${ }^{13}$.

En el análisis de esta posible aplicación del principio de reciprocidad en el sistema de la orden europea de detención y entrega nos detendremos a exponer cuál es la postura de nuestro Tribunal Constitucional al respecto.

diferentes desde un punto de vista cualitativo por cuanto la extradición es un procedimiento político en tanto la euroorden es puramente técnico-jurisdiccional. Vid. CUERDA RIEZU, A., "La extradición y la Orden Europea de Detención y Entrega", en Revista CENIPEC núm. 25, Vol I, Enero-Diciembre 2006, pp. 54-57; ARANGÜENA FANEGO, C., "La orden europea de detención y entrega. Análisis de las Leyes 2 y 3 de 14 de marzo de 2003, de transposición al ordenamiento jurídico español de la Decisión Marco sobre la «euro-orden»", Revista de Derecho Penal (Lex Nova), núm. 10, 2003, pág. 19.

12 Control que debe llevarse a cabo una vez concluida la fase judicial del procedimiento de extradición. Vid. artículos 1.2 y 6 LEP y 278.2 LOPJ.

13 Vid. Artículo 6 Ley 23/2014, de 20 de noviembre, de reconocimiento mutuo de resoluciones penales en la Unión Europea (BOE núm. 282, de 21 de noviembre de 2014), en adelante LRM, que deroga, entre otras, la ley española de transposición de la Decisión Marco del Consejo 2002/584/ JAI, de 13 de junio de 2002, relativa a la orden de detención europea y a los procedimientos de entrega entre Estados miembros (DOUE L 190 de 18 de julio de 2002), esto es, la Ley 3/2003, de 14 de marzo, sobre la orden europea de detención y entrega (BOE núm. 65, de 17 de marzo de 2003). 
Para finalizar, atendiendo a la ausencia de regulación normativa del principio de reciprocidad, tanto en la normativa europea que regula el procedimiento de la orden europea de detención y entrega, esto es, en la Decisión Marco 2002/584/JAI ${ }^{14}$, como en la norma española de transposición ${ }^{15}$, y al criterio del Tribunal Constitucional que reconoce la ausencia de reciprocidad en la eurorden, pondremos de manifiesto las razones que nos llevan a afirmar por un lado que, efectivamente, dicha reciprocidad no tendría cabida en el procedimiento de la euroorden y, por otro lado, que no resultaría aplicable al mismo el mandato constitucional que regula el principio de legalidad extradicional dado que, desde nuestro modesto punto de vista, nos encontramos ante instrumentos de cooperación judicial distintos.

A pesar de nuestra afirmación anterior, no podemos dejar de reconocer que la ausencia de previsión normativa de la reciprocidad en los textos que regulan el procedimiento de la orden europea de detención y entrega, tanto en el ámbito europeo como en el nacional, no implica una eliminación expresa de este principio básico de la extradición. Antes al contrario, dicha omisión podría reflejar la idea de que se ofrece la posibilidad a los Estados de condicionar, en la medida de lo posible, la entrega de la persona reclamada al cumplimiento del requisito de la reciprocidad entendiéndose que dicho principio se encuentra implícito en el procedimiento de la euroorden.

14 Para un profundo análisis sobre la orden europea de detención y entrega se puede consultar la obra de PÉREZ CEBADERA, M.A., La nueva extradición europea: la orden de detención y entrega, Ed. Tirant lo Blanch, Valencia 2008.

15 Ley 23/2014, de 20 de noviembre, de reconocimiento mutuo de resoluciones penales en la Unión Europea (BOE núm. 282, de 21 de noviembre de 2014), en adelante LRM. 


\section{Breve referencia al principio de reciprocidad como principio básico del Derecho internacional}

El principio de reciprocidad es un principio universalmente aceptado en las relaciones internacionales entre los Estados. Tanto es así que se convierte en uno de los principios fundamentales del Derecho Internacional, tanto público como privado. En este sentido, el principio de reciprocidad supone, ante la ausencia de reglas normativas aplicables o como consecuencia de lo previsto en la norma aplicable a una materia, la adopción por parte de los Estados de una determinada conducta similar o proporcionada a la adoptada por el otro Estado.

Sobre la base de un concepto general del principio de reciprocidad, este principio supone que los Estados asumen derechos y obligaciones en función de un trato recíproco, pero sin olvidar que no se trata exclusivamente de un mero reconocimiento formal, sino que nos encontramos ante un principio que va a exigir que, tras dicho reconocimiento formal, los Estados actúen de modo que de manera expresa reconozcan los derechos de los otros Estados ${ }^{16}$.

Desde el punto de vista técnico-jurídico, y en concreto para el Derecho Internacional Privado, la reciprocidad implica que la aplicación del Derecho interno de un país a una persona física o jurídica no nacional de ese Estado se supedita al trato que se dé en aquel Estado a los nacionales de este país. En otras palabras, la ley territorial se aplica a los extranjeros residentes siempre que la del Estado al que pertenecen prevea idéntico trato para los nacionales de aquel Estado ${ }^{17}$.

16 Vid. BUENO ARÚS, F., "El principio de reciprocidad en la extradición y la Legislación española", en Anuario de derecho penal y ciencias penales, Tomo 37, 1984, pág. 69.

17 En el ámbito del Derecho Internacional Privado, en el Ordenamiento jurídico español, se hace referencia al principio de reciprocidad, por ejemplo, en el capítulo IV del Título Preliminar del Código Civil, donde el artículo 9.5 establece expresamente que "No será reconocida en 
En el marco del derecho internacional público, teniendo como sujetos a los Estados, la reciprocidad alude de manera esencial a la noción de "aplicación por la otra parte"18. Esto es, siguiendo a TRÍAS y GIRÓ, la reciprocidad diplomática, distinta de la reciprocidad legislativa ${ }^{19}$.

Haciendo un breve repaso por los orígenes de este principio partimos de la aplicación del principio de reciprocidad en el XVII como solución a los límites que derivan de la aplicación del principio de territorialidad en el tráfico internacional. Este principio de Comitas Gentium o, lo que es lo mismo, de "cortesía internacional" o "recíproca utilidad", nace como consecuencia de las restricciones que el reconocimiento de la territorialidad imponía, en aquel momento, al creciente tráfico internacional ${ }^{20}$.

España como adopción la constituida en el extranjero por adoptante español, si los efectos de aquélla no se corresponden con los previstos por la legislación española. Tampoco lo será, mientras la entidad pública competente no haya declarado la idoneidad del adoptante, si éste fuere español y estuviera domiciliado en España al tiempo de la adopción”.

18 Vid. Artículo 47 de la Convención de Viena, sobre Relaciones Diplomáticas que, en su inciso 1, afirma que el Estado receptor no puede efectuar actos discriminatorios que afecten a otros países. Sin embargo, el inciso 2 letra $\mathrm{b}$, determina que no se puede entender como discriminación el hecho de que, "por costumbre o acuerdo, los estados se concedan reciprocamente un trato más favorable" que el requerido en las disposiciones de un tratado. Convención de Viena sobre Relaciones Diplomáticas, 18 de abril de 1961 (BOE núm. 21, de 24 de enero de 1968).

19 TRÍAS y GIRÓ, J., Estudios de Derecho Internacional Privado, con aplicación especial al Derecho español, Sociedad General de Publicaciones, Barcelona 1921.

20 Dado que el objetivo de este trabajo de investigación no es llevar a cabo un estudio exhaustivo del principio de reciprocidad, sino una breve referencia a la aplicación, con carácter general, de este principio y su implicación en el procedimiento de la extradición, remitimos para un estudio sobre esta materia a la obra de PAN MONTOJO, F., "Estudio de la reciprocidad en la doctrina, legislación y jurisprudencia", en Revista Española de Derecho Internacional (REDI), núm. 9 (1-2), 1956, pp. 147-172. 
A partir de ahí, la reciprocidad se convierte en una máxima del derecho que los Estados aplican en sus relaciones internacionales, ya sea como consecuencia de la ausencia de norma que regule una materia en particular o, por el contrario, como complemento de alguna norma existente, en respuesta simétrica a la conducta del otro Estado.

Sin embargo, resulta necesario recordar que la reciprocidad no supone la exigencia de una equivalencia absoluta entre los actos realizados por las partes entre sí $^{21}$. La reciprocidad, por el contrario, tiene como objetivo implementar la confianza mutua entre Estados y debe, asimismo, servir de estímulo para que los Estados cumplan las normas internacionales y las obligaciones de largo plazo acordadas entre ellos. Así, como afirma PASTRANA BUELVAS, el principio de reciprocidad provoca que los estados cumplan los acuerdos contraídos sin ningún tipo de coacción, de tal manera que, en palabras de este autor, el principio de reciprocidad es considerado como "...el motivo sociológico más fuerte para la observancia del derecho internacional, es decir, como garante para su efectividad"22.

Podemos sintetizar el significado de este principio afirmando que se trata básicamente de que los Estados asuman derechos y obligaciones sobre la base de un trato recíproco. No obstante, no se trata, como advertíamos anteriormente, de que los Estados expresen un reconocimiento formal, sino que la reciprocidad exige que dicho reconocimiento formal

21 Cfr. STC 87/2000, de 27 de marzo (ECLI:ES:TC:2000:87) que afirma que "la determinación del contenido y alcance del principio de reciprocidad constituye una cuestión susceptible de diversas interpretaciones, en particular en lo atinente al grado de similitud, o incluso identidad, de los supuestos de hecho, que constituye el presupuesto para exigir al Estado requirente garantía de reciprocidad".

22 Vid. PASTRANA BUELVAS, E., "El principio de la no-reciprocidad: entre el deber ser y su regulación jurídica en el marco de las relaciones económicas internacionales y de cooperación”, en Papel Político núm. 17, junio de 2005, pág. 91 . 
vaya seguido de un determinado comportamiento por parte de un Estado y que, sobre la base de dicho comportamiento se reconozcan los derechos de otro Estado por reciprocidad.

La concepción territorial del ejercicio de competencias soberanas implica que los Estados van a poder ejercer dichas competencias con exclusividad ${ }^{23}$, por lo que el principio de reciprocidad va a proporcionar a los Estados la posibilidad de hacer efectivos sus derechos en el territorio de otro Estado sobre la base de un comportamiento recíproco. Este trato recíproco puede, o no, tener un origen convencional, aunque cada vez con mayor frecuencia se tiende a incorporarlo en determinado tipo de Tratados internacionales, como son, a modo de ejemplo, los referidos al procedimiento de la extradición en el ámbito penal; los que tengan por objeto el reconocimiento de beneficios fiscales a los nacionales de sus respectivos Estados en el territorio de otro Estado Parte; los que reconocen derechos a los nacionales de otro Estado Parte igual que los que reconocen a sus propios nacionales, cuando dichos extranjeros se encuentren en su territorio; o, por ejemplo, los que reconocen las decisiones judiciales tomadas por órganos jurisdiccionales de otro Estado.

Cuando no existe la obligación convencional de seguir un determinado comportamiento de un Estado hacia otro, este principio adquiere una mayor importancia, si cabe, en materia de cooperación internacional. En opinión de GUISADO LITTERIO “...tanto el principio de solidaridad como el de reciprocidad encuentran su principal relevancia ante la ausencia de marcos convencionales jurídicamente vinculantes que impongan a los Estados la obligación de cooperar..." ${ }^{24}$.

23 “... el principio de soberanía.... expresa la reciprocidad de derechos y deberes de los Estados, la sumisión directa de éstos al Derecho internacional'. CARRILlO SALCEDO, J. A., Soberanía del Estado y Derecho Internacional, Ed. Tecnos, Madrid 1969, pág. 69.

24 GUISADO LITTERIO, T. M., "La extradición fuera de un marco convencional: la operación de los principios de reciprocidad y solidaridad 
En cualquier caso, la aplicación de este principio nunca debería suponer una descompensación de esfuerzos entre los Estados implicados, de tal forma que uno de los Estados obtenga un beneficio en claro detrimento del otro. El trato recíproco debería implicar, también, un trato recíproco justo. De hecho, como pone de manifiesto PLANTEY "el respeto a la reciprocidad da origen a la buena fe y al crédito entre los Estados"25.

No podemos negar que el principio de reciprocidad, desde el punto de vista del derecho internacional, es uno de los principios de mayor relevancia que resulta, además, aplicable en una gran variedad de ámbitos. No obstante, esto no puede llevarnos a la conclusión de que nos encontremos ante un principio cuya aplicación resulte adecuada en todos los ámbitos pues, como afirma GUZMAN, el principio de reciprocidad en relación con los derechos humanos se convierte en un obstáculo incompatible con la protección de dichos derechos $^{26}$. Sin embargo, SÁNCHEZ LEGIDO pone de manifiesto que "el respeto de los derechos fundamentales no puede ser contemplado como una posible amenaza frente a la necesaria cooperación judicial penal, sino como el presupuesto

internacionales", en Estándares internacionales de protección de derechos humanos aplicables al instituto de extradición, S. González Napolitano (dir.), SGN Editora, Buenos Aires 2018, pág. 69.

25 PLANTEY A., Tratado de Derecho Diplomático. Teoría y práctica, (trad. de la $2^{\text {a }}$ edición francesa por IGLESIAS SANZ A.) Madrid 1992, pág. 768.

26 GUZMAN, A., How international law works: Introduction. International Theory, 1(2), 2009, pp. 285-293 y DONDÉ MATUTE, J., "Extradición y Derechos Humanos", en Extradición y debido proceso, Ed. INACIPE, México 2017, pág. 23. Como afirma BENAVIDES CASALS "la reciprocidad que informa al derecho de los tratados, no se adecúa completamente al ámbito de los derechos humanos". Cfr. BENAVIDES CASALS, M.A., "Reservas en el ámbito del Derecho Internacional de los Derechos Humanos", Ius et Praxis, Vol. 13, núm. 1, 2007 (versión On-line ISSN 0718-0012), disponible en https://scielo.conicyt.cl/scielo. php?script=sci_arttext\&pid=S0718-00122007000100007 (última consulta, 30.10.2020). 
existencial de la confianza mutua sobre la que esta última se sustenta" 27 . Es ante esta permanente falta de confianza mutua cuando se recurre a una cooperación basada en la idea del citado Comitas Gentium sobre el que descansa el principio de reciprocidad que no significa finalmente otra cosa que dar marcha atrás en la construcción de un espacio común que garantice la justicia ${ }^{28}$. Ello, sin embargo, no obsta a reconocer que nos encontramos ante un principio que, sin duda alguna, en el ámbito de las relaciones internacionales, tradicionalmente, ha favorecido la cooperación judicial internacional entre Estados soberanos, concretamente, en materia de reconocimiento y ejecución de resoluciones judiciales ${ }^{29}$.

A pesar de todo lo expuesto parece que en la actualidad este principio de reciprocidad, en el ámbito de la cooperación jurídica civil, comienza a perder relevancia. La razón que nos lleva a esta conclusión la podemos encontrar, precisamente en España, con la relativamente reciente, y ya citada, Ley de cooperación jurídica en el ámbito civil, donde el principio de reciprocidad se convierte, directamente, en un principio con carácter residual ${ }^{30}$.

27 SÁNCHEZ LEGIDO, A., "La euro-orden, el principio de doble incriminación y la garantía de los Derechos fundamentales", op.cit., pág. 54.

28 ARNÁIZ SERRANO, A., "Evolución de la Cooperación Judicial Penal Internacional: en especial, la Cooperación Judicial Penal en Europa", Consejo General del Poder Judicial, $5^{\text {a }}$ edición, 2013, pág. 35 (disponible en http://www5.poderjudicial.es/cvep12-13/CVCP13-01-ES.pdf).

29 Para un detenido estudio acerca de los principios del Derecho internacional Vid. VELAZQUEZ ELIZARRARAS, J. C., "Reflexiones generales en torno a la importancia de los principios del derecho internacional". Anuario Mexicano de Derecho Internacional (online), vol.12, 2012, pp.407-453. Disponible en http://www.scielo.org.mx/scielo. php?script=sci_arttext\&pid=S1870-46542012000100012. (Última revisión 30.10.2020).

30 Sin embargo, no podemos dejar de señalar que, tal y como se pone de manifiesto en el Preámbulo de la LCJI, el Título V supone una revisión de la normativa sobre el reconocimiento y ejecución de decisiones extranjeras teniendo en cuenta, por un lado, que nos encontramos en un ámbito especialmente relevante puesto que, precisamente, este 
El motivo que lleva al legislador a atribuirle carácter residual al principio de reciprocidad no es otro que la necesidad de garantizar a los ciudadanos la tutela judicial internacional efectiva de sus derechos e intereses legítimos. De ahí que el principio de reciprocidad comience a adquirir ante la falta de seguridad jurídica, en este ámbito específico, el carácter de principio accesorio o de carácter secundario. Con esta relevante transformación en la aplicación accesoria del principio de reciprocidad, los Estados tratan de evitar que los ciudadanos sufran los efectos negativos de la falta de reciprocidad entre los Estados ${ }^{31}$.

En este sentido, además, en el ámbito de la cooperación civil, debemos advertir que el principio de reciprocidad ya no sirve como instrumento para lograr el cambio de actitud en los Estados extranjeros, tanto es así que la mencionada ley hace referencia a la reciprocidad exclusivamente como medida a adoptar por el Gobierno en los supuestos en los que los Estados se nieguen de forma reiterada a cooperar con las autoridades españolas ${ }^{32}$. Efectivamente, la LCJI,

principio de reciprocidad rige en los Tratados y Reglamentos de la Unión Europea, por lo que únicamente serán aplicables en lo que respecta a resoluciones judiciales emitidas por las autoridades judiciales de Estados parte en dichos instrumentos y relativas a materias cubiertas por los mismos.

31 La exigencia de la reciprocidad entre los Estados es menor como consecuencia lógica de una mayor cesión de soberanía legislativa y jurisdiccional, siendo así que el voluntarismo se suprime progresivamente por la fuerza coactiva del derecho.

32 Vid. Artículo 3 LCJI, ya citado, rubricado Principio general favorable de cooperación, y que establece:

"1. Las autoridades españolas cooperarán con las autoridades extranjeras en las materias objeto de esta ley conforme a lo establecido en el artículo anterior.

2. Pese a no exigirse reciprocidad, el Gobierno podrá, mediante real decreto, establecer que las autoridades españolas no cooperarán con las autoridades de un Estado extranjero cuando exista una denegación reiterada de cooperación o prohibición legal de prestarla por las autoridades de dicho Estado”. 
"....como mecanismo de salvaguarda frente al "salto al vacío" que conlleva toda oferta unilateral de cooperación jurídica, ...incluye una serie de cláusulas generales llamadas a proteger nuestros principios constitucionales, la soberanía o la seguridad nacional"33.

Aunque resulta del todo innecesario por tratarse de una cuestión que nadie puede poner en duda, no podemos dejar de recordar que el principio de reciprocidad ha sido considerado tradicionalmente el fundamento para el reconocimiento mutuo de decisiones judiciales entre Estados ${ }^{34}$. Los Estados tradicionalmente han pretendido dotar a sus resoluciones judiciales de eficacia jurídica no sólo en su territorio, sino también fuera de sus fronteras y para ello como es lógico deben, igualmente, reconocer eficacia a las decisiones judiciales de otros Estados ${ }^{35}$.

Sin embargo, en la actualidad, y como advertíamos anteriormente, la tendencia es la de suprimir el principio de reciprocidad en materia de reconocimiento de resoluciones

33 Vid. AA.VV., "Una propuesta de Ley de cooperación jurídica internacional en materia civil", op. cit., pág. 10. GUZMÁN ZAPATER contempla este mecanismo de salvaguarda como motivo "político" de oposición y que, como tal, corresponde establecerlo al Ministerio de Justicia y por Real Decreto. Vid. GUZMÁN ZAPATER, M., "Artículo 14. Motivos de denegación", Comentarios a la ley de cooperación jurídica internacional en materia civil, MÉNDEZ GONZÁLEZ, F.P., y PALAO MORENO, G., (dirs.), Ed. Tirant lo Blanch, Valencia 2017, pág. 164.

$34 \mathrm{El}$ art. 82.1 del TFUE afirma que "la cooperación judicial en materia penal en la Unión se basará en el principio de reconocimiento mutuo de las sentencias y resoluciones judiciales". Sobre el principio de reconocimiento judicial mutuo Vid. BUENO JIMÉNEZ, M., "Hacia una cooperación judicial en la Unión Europea: el reconocimiento mutuo de resoluciones judiciales en el ámbito penal", disponible en http://noticias. juridicas.com/conocimiento/articulos-doctrinales/11954-hacia-unacooperacion-judicial-en-la-union-europea:-el-reconocimiento-mutuode-resoluciones-judiciales-en-el-ambito-penal/. Última revisión, junio 2020.

35 Vid. ROCA FERNÁNDEZ, M.J., "El principio de reciprocidad y las relaciones internacionales de la Santa Sede", en Revista Española de Derecho Canónico, Vol. 65, № 164, 2008, pág. 134. 
judiciales ${ }^{36}$. Así, nuestra Ley Orgánica del Poder Judicial (en adelante, LOPJ), tras la reforma operada por la Ley $7 / 2015^{37}$, en relación a la ejecución de las solicitudes remitidas por autoridades judiciales extranjeras solo hace referencia a la obligación de cumplimentarlas según lo que establezcan los convenios internacionales, eliminando la remisión expresa a la reciprocidad en ausencia de éstos ${ }^{38}$.

No obstante, como afirma ROCA FERNÁNDEZ, "conviene advertir que, aunque pudiera parecer paradójico, en las relaciones entre Estados no existen grandes diferencias, en cuanto al principio de reciprocidad se refiere, entre los supuestos regulados mediante acuerdo y aquellos otros en los que se da ausencia de tratado. En el caso de que exista un tratado, a la postre, es igualmente un criterio de reciprocidad el que se está aplicando" ${ }^{39}$.

Al igual que anteriormente reconocíamos que en el ámbito de la cooperación judicial civil el legislador español se mostraba proclive a la eliminación de este principio de

36 RODRÍGUEZ BENOT hace incluso referencia al “...el moribundo régimen de reciprocidad...". Cfr. RODRÍGUEZ BENOT, A., "La ley de cooperación jurídica internacional en materia civil", Cuadernos de Derecho Transnacional (Marzo 2016), Vol. 8, núm 1, pág. 250.

37 Cfr. artículo 277 LOPJ. Asimismo, en el artículo 278 LOPJ se regulan los motivos de denegación de la asistencia judicial requerida $\sin$ hacer referencia previamente a la existencia de reciprocidad entre Estados. Precisamente el TC, en las sentencias 83/2006, de 13 de marzo (ECLI:ES:TC:2006:83) y 293/2006, de 10 de octubre, (ECLI:ES:TC:2006:293), afirma que, en realidad, el fundamento del principio de reciprocidad no tiene conexión directa con los motivos de denegación del procedimiento de la extradición, ya sean legales o constitucionales, referidos a las condiciones procesales y materiales del asunto penal del que trae causa la solicitud de extradición o de la entrega.

38 Vid. BACHMAIER WINTER L., "La cooperación judicial en asuntos penales en Europa: consideraciones prácticas, situación actual y propuestas de futuro", en El derecho procesal español del siglo XX a golpe de tango, Ed. Tirant lo blanch, Valencia 2012, pág. 1186.

39 Vid. ROCA FERNÁNDEZ, M.J., "El principio de reciprocidad y las relaciones internacionales de la Santa Sede”, op.cit., pág. 136. 
reciprocidad, el Código modelo de Cooperación interjurisdiccional para Iberoamérica en el artículo 2 (IV), entre los principios generales incluye precisamente "la no dependencia al principio de reciprocidad de tratamiento" pero, en lo que a nosotros nos interesa en este trabajo, sin embargo, mantiene como excepción para la cooperación judicial penal y, concretamente para el procedimiento de la extradición, la aplicación de dicho principio de reciprocidad ${ }^{40}$.

En conclusión, como afirma PLANTEY, la reciprocidad no es otra cosa que la aplicación de dos principios: el principio de seguridad y el principio de soberanía ${ }^{41}$. Además, "tal reciprocidad no es matemática, ni jurídica, ni moral, sino política: en efecto, cada parte la aprecia en función de sus intereses y de su supremacía. La reciprocidad es una búsqueda de igualdad y de dignidad, pero un Estado siempre puede renunciar a exigirla"42.

Para finalizar, debemos recordar que el principio de reciprocidad supone un principio general en el ámbito del Derecho internacional en los Estados de tradición de derecho continental y al que le atribuyen el efecto de un pacto vinculante $^{43}$. Sin embargo, en los países de common law ${ }^{44}$ la

40 Cfr. Código modelo de cooperación interjurisdiccional para Iberoamérica en Revista Internauta de Práctica Jurídica Núm. 22, año 2008, pp. 89-11689.

41 Aun cuando pudiera pensarse que nos encontramos ante dos principios con intereses contrarios, puesto que la soberanía justificaría precisamente la reciprocidad en tanto la seguridad jurídica la desplaza, en el ámbito de las relaciones diplomáticas basadas en la reciprocidad se logra un alto grado de seguridad jurídica en opinión de PASTOR RIDRUEJO, J.A., Curso de Derecho Internacional Público y Organizaciones internacionales, Ed. Tecnos, $23^{\text {a }}$ edición, Madrid 2019, pág. 517.

42 Vid. PlanTeY A., Tratado de Derecho Diplomático. Teoría y práctica, op.cit., pág. 763 .

43 Sobre el análisis de la naturaleza jurídica del compromiso de reciprocidad Vid. GUISADO LITTERIO, T.M., "La extradición fuera de un marco convencional: la operación de los principios de reciprocidad y solidaridad internacionales", op.cit., pp. 74-76. 
reciprocidad no adquiere la condición de principio obligatorio ${ }^{45}$. Así, en el derecho continental los Estados prevén el principio de reciprocidad ante la ausencia de tratados, cosa que no sucede en los países de common law que siguen el criterio de no extraditar ante la ausencia de tratado $^{46}$.

\section{El principio de reciprocidad como principio constitucional de la extradición}

No es el momento de entrar en el análisis del concepto de extradición, ni si quiera de realizar un breve recorrido del trámite procedimental de esta institución; ni tampoco se analizará la naturaleza del principio de reciprocidad como criterio político-discrecional ${ }^{47}$ o principio susceptible de control objetivo ${ }^{48}$, pues queda lejos del objetivo fundamental de

44 Para un profundo análisis acerca de las principales diferencias entre los sistemas jurídicos continentales y los sistemas jurídicos del common law, se puede consultar FALCON Y TELLA, M.J., "La equity angloamericana”, en Foro, Nueva época, núm. 1/2005, pp. 79-108.

45 Vid. Manual de asistencia judicial recíproca y extradición de la Oficina de las Naciones Unidas contra la droga y el delito Viena 2012, pág. 23 (Disponible en https://www.unodc.org/documents/organized-crime/Publications/Mutual_Legal_Assistance_Ebook_S.pdf). Última revisión, junio 2020 y PAN MONTOJO, F., "Estudio de la reciprocidad en la doctrina, legislación y jurisprudencia”, op.cit., pág. 153.

46 Cfr. GUISADO LITTERIO, T.M., "La extradición fuera de un marco convencional: la operación de los principios de reciprocidad y solidaridad internacionales", op.cit., pág. 73.

47 En opinión de PASTOR BORGOÑÓN el principo de reciprocidad es un principio político y como tal, su control debe llevarse a cabo en la fase gubernativa del procedimiento de extradición. Vid. PASTOR BORGONON, B., Aspectos procesales de la extradición en Derecho español, Ed. Tecnos, Madrid 1984, citado por BUENO ARUS, F., "El principio de reciprocidad en la extradición y la Legislación española”, op.cit., pág. 76.

48 Como afirma DE LA QUADRA SALCEDO-JANINI "Es por lo tanto necesario diferenciar entre, por un lado, la apreciación que podemos denominar política de la reciprocidad, por requerir una evaluación de las actuaciones judiciales o gubernativas del país requirente y que, en el tradicional sistema de extradición, debe quedar en manos de las 
nuestro estudio ${ }^{49}$. Hecha esta advertencia queremos, además, poner de manifiesto que nuestro objetivo en este apartado va dirigido a analizar la relevancia que tiene el principio de reciprocidad en el procedimiento de la extradición. Para ello no podemos sino partir de su reconocimiento como principio con categoría constitucional en virtud de lo previsto en el, ya citado, artículo 13.3 de nuestra Constitución.

Como todos sabemos, la extradición supone una de las máximas expresiones de la cooperación jurídica entre los diferentes Estados. Es un proceso formal a través del cual un Estado requiere a otro Estado la entrega de una persona acusada de un delito o condenada por éste, bien para el ejercicio de las acciones penales, bien para el cumplimiento de la condena ya impuesta en el Estado requirente ${ }^{50}$.

autoridades gubernativas españolas como consecuencia de la dificultad de que sea apreciada por un órgano jurisdiccional; de, por otro lado, aquella apreciación jurídica de la reciprocidad que puede ser realizada por las autoridades judiciales por requerir una interpretación de normas jurídicas". Cfr. DE LA QUADRA SALCEDO-JANINI "La orden europea de detención y entrega y el principio constitucional de reciprocidad", op.cit., pág. 14.

49 Sirvan estas líneas en nota a pie de página a modo de breve recordatorio de los diferentes procedimientos de extradición, a cuya regulación normativa ya hemos hecho referencia anteriormente, en función de qué Estado solicita la detención y entrega de la persona requerida (extradición activa) y qué Estado debe acceder o denegar dicha entrega (extradición pasiva). La primera, es la extradición considerada desde la perspectiva del Estado requirente, es decir, cuando el Juez o Tribunal competente que conoce de un procedimiento judicial penal, solicita la extradición. En la segunda, el procedimiento de la extradición pasiva tiene lugar cuando se analiza la petición de extradición desde el punto de vista del Estado requerido. A su vez, existe lo que se ha dado en llamar, extradición en tránsito, para aquellos supuestos en los que, para ejecutar la extradición y proceder a la entrega de la persona requerida al Estado requirente, la persona reclamada debe atravesar un tercer Estado que debe, a su vez, autorizar la extradición.

50 Como afirma MORENO CATENA "Desde el punto de vista internacional es por eso un acto de relación entre dos Estados que genera derechos y obligaciones mutuas. Procesalmente se trata de un elemental 
El proceso de extradición en España supone un acto de auxilio judicial internacional de naturaleza mixta (gubernativa y judicial), que supone la intervención y aceptación de la entrega de la persona reclamada tanto por parte del Gobierno como de los órganos jurisdiccionales ${ }^{51}$.

Dado que, como afirma PAN MONTOJO, "el sistema de Derecho internacional privado se basa sobre una base de reciprocidad" 52 , tras analizar lo que se podría denominar una reciprocidad global, es decir, la reciprocidad de los Estados como fundamento de Derecho internacional, nosotros nos vamos a centrar, a partir de este momento, en la interpretación que de este principio debe realizarse en el campo específico del procedimiento de extradición que, como todos sabemos, supone un instrumento habitual de asistencia jurídica internacional entre dos Estados en el mutuo respeto de sus soberanías en cumplimento de las normas de Derecho internacional. Ahora bien, no podemos olvidar que los Estados regularán en su propia Constitución y leyes internas cuáles sean los requisitos materiales y el procedimiento para llevar a cabo dicho auxilio judicial internacional ${ }^{53}$.

Concretamente en el ordenamiento jurídico español, el artículo 13.3 de la Constitución Española establece que "la

acto de asistencia judicial. Penalmente la extradición no es más que el reconocimiento de la extraterritorialidad de la Ley de un país en el ejercicio legítimo de «ius punendi»". Vid. MORENO CATENA, V., "La extradición pasiva", en Proceso Penal, Ed. Tirant lo blanch, Valencia 2020, pag. 1 (TOL20.290).

51 La doctrina clásica define la extradición como “... el acto por el cual un Estado solicita de otro la entrega de un inculpado o de un condenado u ofrece entregar éstos al Estado requirente para hacer posibles los fines del proceso penal declarativo o la ejecución de la sentencia, en su caso". Cfr. HERCÉ QUEMADA, V., y GÓMEZ ORBANEJA, E., Derecho Procesal Penal, 10a edición, Madrid 1987, pp. 394 y 395.

52 Vid. PAN MONTOJO, F., "Estudio de la reciprocidad en la doctrina, legislación y jurisprudencia”, op.cit., pág. 147.

53 Sobre la evolución histórica del principio de reciprocidad como requisito previo de la extradición Vid. BUENO ARÚS, F., "El principio de reciprocidad en la extradición y la Legislación española", op.cit., pág. 68. 
extradición sólo se concederá en cumplimiento de un tratado o de la ley, atendiendo al principio de reciprocidad" 54 . Y, es el artículo 1 de la Ley 14/1985, de 21 de marzo, de extradición pasiva el que incorpora este principio cuando determina que "el Gobierno podrá exigir una garantía de reciprocidad al Estado requirente" 55 .

54 En palabras del propio TC "Esta garantía, incluida en la máxima nulla traditio sine lege, obedece a distintas finalidades. Por una parte, pretende que la extradición quede sometida básicamente a reglas jurídicas y no exclusivamente a la voluntad de los Estados, que no pueden extraditar arbitrariamente a quienes se encuentran en su territorio, según se deriva del artículo 9 de la Declaración Universal de Derechos Humanos, del artículo 5.1 f) del Convenio Europeo para la Protección de los Derechos Humanos y del artículo 13 del Pacto Internacional de Derechos Civiles y Políticos. Por otra parte, el principio nulla traditio sine lege supone subordinar a normas adoptadas por los legítimos representantes la actuación de los órganos judiciales que contribuyen a la decisión favorable o desfavorable respecto a la entrega. Y, finalmente, permite ofrecer a los destinatarios una mayor seguridad jurídica, en atención a la necesaria previsibilidad de las consecuencias de los propios actos, en relación con una medida como la extradición que determina efectos perjudiciales en la esfera del afectado y, en sentido amplio, en su derecho a la libertad". Vid. SSTC 141/1998, de 29 de junio (ECLI:ES:TC:1998:141) y 30/2006, de 30 de enero (BOE núm. 51, de 1 de marzo de 2006. ECLI:ES:TC:2006:30).

55 El procedimiento de extradición activa, sin embargo, se regula en la Ley de Enjuiciamiento Criminal, en los artículos 824 a 833 y es concretamente el artículo 827, en relación con los requisitos exigidos para proceder a la extradición, el que establece que "... en defecto de los dos casos anteriores, cuando la extradición sea procedente atendiendo a la reciprocidad" (Real Decreto de 14 de septiembre de 1882 por el que se aprueba la Ley de Enjuiciamiento Criminal. BOE núm. 260, de 17 de septiembre de1882). En cuanto a la prelación de fuentes normativas en relación con la extradición pasiva, en primer lugar, resultan de aplicación los tratados internacionales ratificados por España y publicados en el Boletín Oficial de Estado (arts. 96.1 Constitución Española y 1.5 Código Civil) y en defecto de éstos, o con carácter supletorio, se aplica la Ley de Extradición Pasiva. En este sentido, Vid. por todas, la sentencia de la sala de lo penal de la Audiencia Nacional, de 14 de mayo de 2015, (RJ núm. 3). ECLI: ES:AN:2015:130. Vide. También PÉREZ MANZANO, M., "El control constitucional de la extradición y la orden europea de detención y entrega", en Comentarios a la Constitución Española, Pérez Manzano, M., y Borrajo Iniesta, I., (Coords), Ed. Wolters Kluwer, Madrid 2018, pp. 302-304. 
Igualmente, en el ámbito europeo, la reciprocidad ha sido considerada un principio básico regulado tanto en el Convenio europeo de extradición de $1957^{56}$, como en el de $1996^{57}$ en vigor para las relaciones entre los Estados miembros de la Unión Europea y terceros Estados, pues el procedimiento de extradición en el ámbito de la Unión Europea fue sustituido por la orden europea de detención y entrega de la que hablaremos más adelante ${ }^{58}$.

Sin embargo, resulta de gran importancia destacar con relación al procedimiento de extradición activa, como advertíamos al comienzo de este apartado, que el Gobierno de un país no puede comprometerse a cumplir con el principio de reciprocidad en tanto en cuanto su propia legislación interna no permita a su Poder Ejecutivo concederla. Esto es, la actuación de los Estados en materia de extradición va a depender de lo que les permita su propio Derecho interno.

Tampoco podemos dejar de recordar que el principio de reciprocidad no supone exactamente una norma reguladora del procedimiento de extradición, sino que en los supuestos en los que el Estado requerido, independientemente

56 De 13 de diciembre de 1957. Instrumento de ratificación de 21 de abril de 1982 (BOE, de 8 de junio de 1982). Sobre los trabajos previo de preparación del Convenio se puede consultar la página web: https://www. coe.int/en/web/conventions/full-list/-/conventions/treaty/024. Última revisión, junio 2020.

57 Convenio de 27 de septiembre de 1996, establecido sobre la base del artículo K.3 del Tratado de la Unión Europea relativo a la extradición entre los Estados miembros de la Unión Europea, hecho en Dublín el 27 septiembre 1996 (DOCE C 313, de 13 de octubre de 1996 y publicado en el BOE de 24 de febrero de 1998 pero que no ha entrado en vigor hasta el 5 de noviembre de 2019).

58 La entrada en vigor de la Orden Europea de Detención y Entrega no trae consigo la derogación del Convenio de 1957, sino que nos encontramos ante dos procedimientos de cooperación jurídica autónomos, que se aplican para un conjunto parecido, aunque no idéntico de países. Vid. Decisión Marco del Consejo, 2002/584/JAI de 13 de junio de 2002, relativa a la orden de detención europea y a los procedimientos de entrega entre Estados miembros (DOCE L 190, de 18 de julio de 2002). 
de lo que venga establecido en los tratados y en el derecho interno que regule la materia, subordine el cumplimiento de la obligación de entrega de delincuentes a las mismas obligaciones por parte del Estado requirente en situaciones similares anteriores, nos encontramos ante una mera condición ${ }^{59}$; una condición de aplicación tanto de los tratados como de la ley interna ${ }^{60}$. Como consecuencia, el TC español reconoce en reiterada jurisprudencia ${ }^{61}$ que el cumplimiento de estas condiciones trae como consecuencia el sometimiento de las extradiciones de las personas reclamadas a lo que se ha denominado principio de legalidad extradicional.

Por otro lado, es importante señalar, en relación con la reciprocidad como principio general de la extradición, a quién corresponde prometer y acordar la reciprocidad pues se tiende a pensar que la reciprocidad es entre órganos jurisdiccionales en lugar de entre Estados ${ }^{62}$. Es más, si los pode-

59 BUENO ARÚS, sin embargo, afirma que la extradición es "una institución de reciprocidad jurídica internacional...”. Cfr. BUENO ARUS, F. "El principio de reciprocidad en la extradición y en la legislación española”, op.cit., pp. 67-69.

60 En esta misma línea Vid. DE MIGUEL ZARAGOZA, J., "Algunas consideraciones sobre la extradición”, disponible en Boletín del Ministerio de Justicia, núm. 1738, pág. 1562. Sobre el principio de reciprocidad Vid. el citado Manual de asistencia judicial recíproca y extradición de la Oficina de las Naciones Unidas contra la droga y el delito, pág. 23.

61 Vid. STC 292/2005, de 10 de noviembre (ECLI:ES:TC:2005:292) y STC 141/1998, de 29 de junio (ECLI:ES:TC:1998:141), que reconoce la aplicación del artículo $13.3 \mathrm{CE}$ al procedimiento de la orden europea de detención y entrega. Según SÁNCHEZ LEGIDO nos encontramos en una primera fase en la que el TC pretende “...desvincular el principio de legalidad extradicional (nulla traditio sine lege) previsto en el art. 13.2 $\mathrm{CE}$, del principio de legalidad penal (nullum crimen, nulla poena sine lege) previsto en el art. 25 CE". Vid. SÁNCHEZ LEGIDO, A., "La euro-orden, el principio de doble incriminación y la garantía de los Derechos fundamentales", en Revista electrónica de estudios internacionales (REEI), núm. 14 (2007), pág. 21.

62 Vid. al respecto, en esta misma línea, DE MIGUEL ZARAGOZA, J., "Algunas consideraciones sobre la extradición", op.cit., pp. 1563, 1570 y 1571 . 
res públicos del Estado infringieran el principio de legalidad extradicional, ya sea por conceder una extradición sin cumplir con las condiciones del principio de legalidad, o por no cumplir el principio de reciprocidad, nos planteamos si dicha infracción implicaría, también, una vulneración de los Derechos Fundamentales de los ciudadanos ${ }^{63}$.

Antes de intentar dar respuesta a esta problemática, debemos recordar que en ningún caso nuestra Constitución reconoce a los ciudadanos el derecho ordinario, y mucho menos fundamental, a la extradición ${ }^{64}$. Como consecuencia, no se puede sino negar la existencia de una vulneración del derecho fundamental a la tutela judicial efectiva regulada en el artículo $24 \mathrm{CE}$ simplemente porque se haya procedido a la entrega de la persona reclamada incumpliendo la exigencia de la reciprocidad establecida en el artículo 13.3 CE. Lo que no es óbice para reconocer, en opinión de DE LA QUADRA-SALCEDO JANINI, que la exigencia de la reciprocidad no supone solo exigir al Estado requirente un respeto de los derechos fundamentales de la persona reclamada, sino que permite exigir un trato recíproco por parte del otro Estado, aun cuando se respetaran los derechos fundamentales de la persona reclamada. Es por ello por lo que este autor considera que el TC se equivoca cuando, en reiteradas sentencias $^{65}$, afirma que el principio de reciprocidad se aplica

63 Vid. DE LA QUADRA-SALCEDO JANINI, T., "La orden europea de detención y entrega y el principio constitucional de reciprocidad", en Revista española de derecho europeo, núm. 18, 2006 (versión electrónica, disponible en BIB 2006/806, pág. 21). Última revisión junio 2020.

64 Esta es la opinión mayoritaria de la doctrina. Vid. por todos CALAZA LÓPEZ, S., "El procedimiento de ejecución de la «euroorden»", en Boletín de la Facultad de Derecho de la UNED, núm. 26, 2005, pág. 397.

65 Vid. las ya citadas STC 177/2006 (ECLI:ES:TC: 2006:177 y STC 30/2006 donde se afirma que, por un lado, la decisión acerca de la exigencia de la reciprocidad es una cuestión de legalidad ordinaria cuya competencia es del juez de la entrega y, por otro lado, que el juez debe intervenir cuando la ausencia del principio de reciprocidad vulnere derechos fundamentales de los ciudadanos (ECLI:ES:TC: 2006:30). 
única y exclusivamente ante una posible vulneración por parte del Estado requirente de los derechos fundamentales de la persona reclamada. Cuestión diferente sería que, junto al incumplimiento del principio de reciprocidad, se infringiera también el derecho fundamental a la tutela judicial efectiva ${ }^{66}$.

Como podemos observar, en relación con el principio de legalidad en el procedimiento de la extradición regulado en el artículo 13.3 CE, surge en la doctrina la duda a cerca de si la vulneración de este principio de legalidad extradicional conlleva también una vulneración de los derechos fundamentales ${ }^{67}$.

Aun cuando no es el objeto fundamental de nuestro de trabajo de investigación haremos una breve referencia a la posible vulneración de los derechos fundamentales de la persona reclamada por el Estado requirente como consecuencia de la ausencia de reciprocidad que, como ya se ha mencionado anteriormente, queda claro que no es un derecho, sino un principio, aunque eso sí, reconocido en el artículo $13.3 \mathrm{CE}^{68}$.

66 DE LA QUADRA-SALCEDO JANINI, T., "El encaje constitucional del nuevo sistema europeo de detención y entrega", Revista Española de Derecho Constitucional, núm. 78, septiembre-diciembre, 2006, pp. 281 y 287. En esta misma línea, aun cuando es partidario de la ausencia de reciprocidad en el sistema de entrega de la orden europea de detención y entrega, SÁNCHEZ LEGIDO afirma, en relación al análisis que realiza del pronunciamiento del TC en la sentencia STC 292/2005, de 10 de noviembre, que remite a su vez, a la ya citada, STC 141/1998 en la que, en ningún caso, el Alto Tribunal está afirmando que el único derecho que pudiera verse afectado por el incumplimiento del principio de legalidad extradicional sea el derecho a la tutela judicial efectiva del artículo 24 CE. Cfr. SÁNCHEZ LEGIDO, A., "La euro-orden, el principio de doble incriminación y la garantía de los Derechos fundamentales", op.cit., pág. 38 , nota a pie 145 .

67 Vid. Por todos el ya citado DE LA QUADRA-SALCEDO JANINI, T., "La orden europea de detención y entrega y el principio constitucional de reciprocidad", op.cit, pp. 21-28.

68 Cfr. LÓPEZ ORTEGA, J.J., "El futuro de la extradición en Europa", en Apéndice a la obra de CEZÓN GONZÁLEZ, C., Derecho extradicional, Ed. Dykinson, Madrid 2003, 307-308. 
Entre los derechos fundamentales que podrían verse afectados por el incumplimiento del principio de reciprocidad en el procedimiento de extradición, comenzamos con el principio de legalidad penal que garantiza el artículo 25.1 $\mathrm{CE}^{69}$.

No entramos en polémica acerca de si un incumplimiento del principio de legalidad extradicional implica automáticamente una vulneración del principio de legalidad penal regulado en el citado precepto constitucional, pues el TC parece haber puesto fin a esta controversia cuando afirma que la ausencia de reciprocidad en el procedimiento de extradición es un requisito para determinar si la persona reclamada puede ser, efectivamente, enjuiciada en un Estado distinto de aquel donde cometió el delito pues el procedimiento de extradición no es un proceso penal en el que se decida acerca de la culpabilidad del reclamado ni en el que se imponga una pena ${ }^{70}$. Siendo así que el principio de legalidad penal que reconoce el artículo 25.1 CE garantiza, pues, el cumplimiento de las normas sustantivas (penales o administrativas) no procesales, no cabe duda alguna que la infracción del principio de legalidad extradicional no supone la vulneración del artículo $25 \mathrm{CE}^{71}$.

69 "Nadie puede ser condenado o sancionado por acciones u omisiones que en el momento de producirse no constituyan delito, falta o infracción administrativa, según la legislación vigente en aquel momento".

70 En cuanto a la primera cuestión Vid. STC 11/1983, Sala segunda, de 21 de febrero (BOE núm. 70 de 23 de marzo de 1983. ECLI:ES:TC:1983:11). Para la segunda cuestión Vid. SSTC 120/2008, de 13 de octubre

(BOE núm. 263, de 31 de octubre de 2008. ECLI:ES:TC:2008:120);156/2002, de 23 de julio, (BOE núm. 188, de 7 de agosto de 2002. ECLI:ES:TC:2002:156) y 83/2006, de 13 de marzo, (BOE núm. 92, de 18 de abril de 2006. ECLI:ES:TC:2006:83).

71 Cfr. STC 30/2006, de 30 de enero (ECLI:ES:TC:2006:30) y 232/2012, de 10 de diciembre (BOE núm. 10, de 11 de enero de 2013. ECLI:ES:TC:2012:232) cuando ambas, en referencia a la STC 141/1998, de 29 de junio (FJ. 3), afirman que “... Desde esta perspectiva la pretendida infracción del principio de legalidad extradicional consagrado en el 
Es la citada STC 11/1983 la que reconoce que, del incumplimiento del artículo $13.3 \mathrm{CE}$, podría derivarse la vulneración de los derechos fundamentales reconocidos no solo en el artículo $25 \mathrm{CE}$, sino también el derecho a la tutela judicial efectiva, el derecho de defensa o el derecho a la presunción de inocencia regulados en el artículo $24 \mathrm{CE}$. Efectivamente, para proceder a la entrega de la persona reclamada por el Estado requirente se debe cumplir el principio de legalidad extradicional, es decir, que la misma, atendiendo además al principio de reciprocidad, debe estar prevista en un tratado o ley ${ }^{72}$. Proceder a la entrega de la persona reclamada sin previsión legal vulneraría el derecho fundamental a un proceso con todas las garantías pues estaríamos ante una decisión judicial que no se ajusta a Derecho ${ }^{73}$.

Encontramos también recursos de amparo ante el TC en el que el recurrente alega la supuesta vulneración de los derechos a la libertad y seguridad reconocidos en el artículo 17.1 $\mathrm{CE}^{74}$ como consecuencia de la infracción del principio de legalidad extradicional. Esto es así porque, si el artículo 13.3 CE exige para acceder a la extradición el cumplimiento del principio de reciprocidad, igualmente debería exigirse

art. 13.3 CE no halla acomodo en el artículo 25.1 CE, puesto que este principio se refiere a las normas penales o sancionadoras administrativas sustantivas, no a las procesales...".

72 Vid., de nuevo, la STC 141/1988, de 29 de junio.

73 En este sentido, como afirma BUENO ARUS, "La reciprocidad puede manifestarse en un acto unilateral (promesa) del Estado requirente, o en un acto bilateral (convenio) que tenga por sujetos a ambos Estados. Cuando el Estado requerido acepte la reciprocidad (la aceptacion puede ser expresa o tacita), el efecto propio de aquella es perfeccionar una obligación de Derecho internacional, convirtiendo en tal la que hasta entonces era solamente una obligacidn o una facultad de Derecho interno". Cfr. "El principio de reciprocidad en la extradición y la Legislación española", op.cit., pág. 75.

74 "Toda persona tiene derecho a la libertad y a la seguridad. Nadie puede ser privado de su libertad, sino con la observancia de lo establecido en este artículo y en los casos y en la forma previstos en la ley". 
dicha reciprocidad para proceder a la privación de libertad como consecuencia de una solicitud de extradición ${ }^{75}$.

En este sentido, el TC, en su sentencia 31/2013, de 11 de febrero, afirma que la vulneración de "...la garantía fundamental de la extradición de que ésta solo pueda ser concedida en cumplimiento de un tratado o de la ley, atendiendo al principio de reciprocidad" produce una vulneración del artículo $17 \mathrm{CE}^{76}$. En opinión de un sector doctrinal, aun cuando el TC ha preferido reconducir la vulneración del principio de legalidad extradicional a la vulneración de los derechos fundamentales reconocidos en el artículo $24 \mathrm{CE}$ en vez de reconocer que la ausencia de legalidad extradicional supone igualmente una vulneración del derecho fundamental protegido en el artículo $17 \mathrm{CE}$, considera que el TC debería tener en cuenta qué derecho fundamental resulta vulnerado como consecuencia del incumplimiento del principio de legalidad extradicional por parte de la autoridad judicial en lo que a su función de control de las decisiones judiciales se refiere ${ }^{77}$.

Es, precisamente, en este punto donde surgen en la doctrina serias dudas acerca del alcance de la función de control del TC, como decíamos anteriormente, sobre la interpretación que el juez ordinario haya hecho de la legislación

75 En relación al alcance del principio de reciprocidad en los supuestos en los que existe acuerdo de extradición entre el estado requerido y estado requirente debemos recordar, como advertíamos anteriormente, que el criterio que acaba aplicándose es, precisamente, el de reciprocidad, entendido como afirma ROCA FERNÁNDEZ “... de la recíproca obligación de dar cumplimiento a lo pactado, no de que el fundamento de lo pactado se base en la reciprocidad". Vid. ROCA FERNÁNDEZ, M.J., "El principio de reciprocidad y las relaciones internacionales de la Santa Sede", op.cit., pág. 133-136.

76 Cfr. STC 31/2013, de 11 de febrero (BOE núm. 61, de 12 de marzo de 2013. ECLI:ES:TC:2013:31).

77 Vid. DE LA QUADRA-SALCEDO JANINI, T., "La orden europea de detención y entrega y el principio constitucional de reciprocidad", op.cit., pág. 22. 
penal. Así, en palabras de FERRERE y MIERES ${ }^{78}$, el problema radica en lograr el equilibrio entre la protección de los derechos fundamentales, en este caso concreto, del derecho a la legalidad penal previsto en el artículo $25 \mathrm{CE}$ y el respeto al principio de exclusividad reconocido en el artículo 117.3 $\mathrm{CE}^{79}$. Pues, no cabe duda de que, cuando el órgano jurisdiccional impone una condena interpretando o seleccionando incorrectamente la legalidad penal, está vulnerando el artículo 25 CE. Sin embargo, como reconocen estos autores, el TC no puede acabar convertido en un tribunal casacional para la unificación de la interpretación de la legalidad penal, pues no siempre el contenido del artículo $25 \mathrm{CE}$ en relación con el órgano jurisdiccional coincide con el contenido del derecho a la legalidad penal en relación con el Tribunal Constitucional y, a nadie escapa, la reserva de jurisdicción prevista en el artículo 117.3 CE.

Siguiendo esta línea de pensamiento, se puede advertir que el TC se encuentra en una encrucijada puesto que si otorga protección constitucional al derecho a la legalidad penal, se involucra, sin duda alguna, en la función jurisdiccional que corresponde en exclusiva a jueces y tribunales. Pero, por otro lado, dejaría vacío de contenido el principio de legalidad penal del artículo $25 \mathrm{CE}$ si no entrara a valorar la decisión judicial desde la perspectiva de dicha legalidad penal.

La solución a esta controversia ${ }^{80}$ la encontramos de nuevo en la jurisprudencia del TC que se decanta por una so-

78 FERRERE COMELLAS, V., y MIERES MIERES, L.J., "Algunas consideraciones acerca del principio de legalidad penal", en Revista española de Derecho Constitucional, núm. 55, 1993, pp. 293-295. (Versión electrónica. Ultima revisión, junio 2020).

79 "El ejercicio de la potestad jurisdiccional en todo tipo de procesos, juzgando y haciendo ejecutar lo juzgado, corresponde exclusivamente a los Juzgados y Tribunales determinados por las leyes, según las normas de competencia y procedimiento que las mismas establezcan".

80 Como indicábamos anteriormente, la controversia radica no tanto en el control de la actividad jurisdiccional en el procedimiento de extradición, 
lución intermedia ${ }^{81}$ cuando reconoce que el propio TC "no es el Juez de la extradición, sino el órgano de control del Juez de la extradición en materia de garantías constitucionales; es decir, al ejercer la función de salvaguarda de los derechos fundamentales de los ciudadanos, no le corresponde al Tribunal Constitucional decidir si una extradición es o no procedente en un caso concreto, sino únicamente si en la decisión judicial que la autoriza, se ha lesionado o no algún derecho fundamental de los constitucionalmente protegidos" $"$.

que está razonablemente clara en nuestro ordenamiento jurídico, sino en el control de la aplicación del principio de reciprocidad, que no forma parte de la decisión judicial, sino de la política y que, como afirmábamos al comienzo de este trabajo, quedaría excluido del control judicial conforme a lo establecido en el, ya citado, art. 6 LEP.

81 FERRERE COMELLAS y MIERES MIERES ofrecen tres posibles soluciones a la colisión de estos derechos fundamentales en un procedimiento de extradición. En primer lugar, se podría partir de la idea de que el TC no tendría por qué analizar si el órgano jurisdiccional ha aplicado correctamente el principio de reciprocidad porque estaríamos ante una cuestión de legalidad ordinaria y, por tanto, fuera del ámbito de protección constitucional. En segundo lugar, se podría considerar que el control de la exigencia de la reciprocidad corresponde al TC para garantizar el cumplimiento del principio de legalidad extradicional. Y, por último, la solución intermedia de la que hablábamos anteriormente, que exige al TC la protección de la persona reclamada por el Estado requirente frente al incumplimiento del artículo 13.3 CE. Esta última opción, permitiría al TC analizar si la decisión judicial ha sido razonable. Es decir, se trataría de que el TC pueda enjuiciar si la decisión judicial ha sido irrazonable o supone un claro error, independientemente que la decisión judicial sea, o no, la decisión correcta. Vid. FERRERE COMELLAS, V., y MIERES MIERES, L.J., "Algunas consideraciones acerca del principio de legalidad penal”, op.cit., pp. 296-302 y DE LA QUADRA-SALCEDO JANINI, T., "La orden europea de detención y entrega y el principio constitucional de reciprocidad", op.cit, pp. 23. Aunque en relación con la orden europea de detención y entrega Vid. STC 30/2006 (ECLI:ES:TC:2006:30), citada en reiteradas ocasiones.

82 Cfr. STC 156/2002, de 23 de julio (BOE núm. 188, de 7 de agosto de 2002. ECLI:ES:TC:2002:156). 


\section{La supresión del principio de reciprocidad en la euroorden, ¿realidad o ficción?}

La extradición ha sido hasta el siglo XX un procedimiento que, desde el punto cuantitativo, ha tenido poca relevancia en el tráfico jurídico internacional ${ }^{83}$. Sin embargo, el resultado de dichos procedimientos de extradición supone un dato importante acerca de cuál es el grado de confianza en los sistemas legales y judiciales entre los Estados ${ }^{84}$. Precisamente partiendo de ese grado de confianza entre los Estados miembros de la Unión Europea ${ }^{85}$, en el procedimiento de la euroorden se suprime la regulación expresa del principio de reciprocidad ${ }^{86}$, al igual que en la citada LCJI que solo

83 Las extradiciones recibidas por España como país de ejecución (extradición pasiva) en el año 2019 han sido 536 frente las 1176 órdenes europeas de detención y entrega recibidas por nuestros órganos jurisdiccionales como autoridades judiciales de ejecución. Por el contrario, las órdenes de detención y entrega emitidas por nuestros órganos jurisdiccionales como autoridades de emisión han sido de 452, las solicitudes de extradición cursadas a otros países ascienden a 186. Datos obtenidos de la página web del Consejo General del Poder Judicial, Justicia Dato a Dato, año 2019, disponible en http://www.poderjudicial.es/cgpj/es/ Temas/Estadistica-Judicial/Estudios-e-Informes/Justicia-Dato-a-Dato/. Última revisión, junio 2020.

84 Para analizar en profundidad los principios que rigen la cooperación judicial tradicional, Vid. NIETO MARTÍN, A., "Introducción", en Código de Derecho penal europeo e internacional (Arroyo Zapatero, L., y Nieto Martín, A., (dirs.), Ministerio de Justicia- UCLM, 2008, pp. 29-31.

$85 \mathrm{Al}$ que hace expresa referencia la citada Decisión Marco en su considerando número $10 \mathrm{y}$ siempre teniendo en cuenta que, aunque todos los Estados de la Unión Europea son miembros del Consejo de Europa, no todos los Estados miembros del Consejo de Europa son miembros de la UE. Como consecuencia de ello, las relaciones en materia de detención y entrega de la persona reclamada entre un Estado de la Unión Europea y un Estado europeo que no pertenezca a la UE, el sistema que rige es el clásico de la extradición.

86 Muestra del interés del legislador en erradicar el principio de reciprocidad de la orden europea de detención y entrega es el fracaso de la propuesta de enmienda del Grupo Parlamentario Socialista a la Disposición Transitoria Segunda (Enmienda número 43) en el sentido de 
se menciona para afirmar, precisamente, que no se exige la reciprocidad pues, como declara el Consejo de Estado, "el abandono del principio de reciprocidad aparece así como una exigencia del derecho a la tutela judicial efectiva, objetivo último de la cooperación jurídica internacional" $"$.

Nuestro Tribunal Constitucional, en la ya citada sentencia 177/2006 $6^{88}$, expresamente ha reconocido que el tradicional principio de reciprocidad que rige en el procedimiento de la extradición no resulta aplicable a la orden europea de detención y entrega pues, en la lucha contra la delincuencia, la norma europea que regula este nuevo instrumento jurisdiccional de cooperación internacional impone a los Estados miembros una serie de obligaciones que no pueden verse condicionadas a la exigencia de la reciprocidad. Estamos ante un sistema de naturaleza jurisdiccional en el que el principio de reciprocidad queda aparentemente descartado ${ }^{89}$. Por el

exigir el principio de reciprocidad respecto de la legislación aplicable en atención al momento de la comisión de los hechos, en atención a que países como Italia y Austria no aplicarán la euroorden más que a los hechos que se comentan después de su entrada en vigor. Cfr. Boletín Oficial de las Cortes Generales. Congreso de los Diputados, serie A, núm. 118-5, de 28 de noviembre de 2002, pág. 35.

87 Vid. el Dictamen de 26 de marzo en el comentario al artículo 3 (disponible en http: //www.boe.es/ buscar/doc.php?id=CE-D-2015-236. Última consulta 30.10.2020). Igualmente, el Consejo General del Poder Judicial se manifiesta en contra de la exigencia del principio de reciprocidad fuera de la cooperación judicial en materia de notificaciones y obtención de pruebas. Vid. Informe al Anteproyecto de ley de cooperación jurídica internacional en materia civil, de 30 de septiembre de 2014, pp. 12-14 (disponible en file:///Users/usuario/Downloads/20141007\%20Antepr $\% 20$ Ley $\% 20$ coop. $\% 20$ jca. $\% 20$ internac. $\% 20$ en $\% 20$ materia $\% 20$ civil. pdf. Última consulta, 30.10.2020).

88 Vid. STC 177/2006, de 5 junio (F.J. 5) donde se afirma que la Decisión Marco "ha creado un nuevo sistema en el que el principio de reciprocidad pierde el papel que tradicionalmente representaba en materia de cooperación internacional en la lucha contra el delito, toda vez que las obligaciones que con ella se imponen a los Estados miembros no pueden ser sometidas a dicha exigencia" (ECLI:ES:TC:2006:177).

89 En el sentido de considerar que el principio de reciprocidad ha sido suprimido en la orden europea de detención y entrega Vid. GÓMEZ 
contrario, en opinión de GONZÁLEZ-CUELLAR la omisión al principio de reciprocidad en la orden europea de detención y entrega no implica que éste no sea aplicable, sino que se considera implícito puesto que estamos antes un sistema en el que debe primar la confianza. Según este autor, "el principio de reconocimiento mutuo de las resoluciones judiciales no excluye, sino que presupone la reciprocidad. Es un plus, no un alterius" $"$.

A partir de esta afirmación trataremos de descifrar, si, efectivamente, el principio de reciprocidad ha sido suprimido de la euroorden o, por el contrario, se trata de otro principio clásico de la extradición que el legislador europeo no ha podido erradicar del sistema de entrega entre los países de la Unión Europea.

En primer lugar, tendríamos que analizar si, como ocurre en el ordenamiento jurídico español, la norma constitucional que regula el principio de legalidad extradicional condicionando la entrega de la persona reclamada al respeto del principio de reciprocidad resulta aplicable a la euroorden. Resumiendo, y en definitiva, ello dependerá de si consideramos el nuevo proceso de la euroorden como un nuevo procedimiento extradicional simplificado y, por tanto, condicionado a la exigencia de la reciprocidad tal y como exige el mencionado artículo $13 \mathrm{CE}^{91} \mathrm{o}$, por el contrario, entendamos que este nuevo sistema de entrega europeo no solo supone

CAMPELO, E., "Orden de detención europea y garantías procesales", en Justicia versus seguridad en el espacio judicial europeo, Ed. Tirant lo blanch, Valencia 2011, pág. 30 y SÁNCHEZ LEGIDO, A., "La euroorden, el principio de doble incriminación y la garantía de los Derechos fundamentales", op.cit., pág. 7.

90 Vid. GONZÁLEZ-CUELLAR SERRANO, N., "Las euroórdenes emitidas por el tribunal supremo de España", Revista Teoría y Título: Derecho. Revista de pensamiento jurídico, núm. 26/2019, pág. (Disponible en TOL7.658.320).

91 Esta es la postura de la doctrina mayoritaria Vid. por todos DE LA QUADRA-SALCEDO JANINI, T., "La orden europea de detención y entrega y el principio constitucional de reciprocidad", op.cit, pp. 11-12. 
un sistema de entrega entre autoridades judiciales que sustituye en el ámbito de la Unión Europea al procedimiento de la extradición, sino que nos encontramos ante instrumentos de cooperación jurídica diferentes ${ }^{92}$. Es en este último caso, al no tratarse de una extradición en sentido estricto, cuando podríamos entender que para proceder a la entrega de la persona reclamada en el procedimiento de la euroorden, no tendría por qué exigirse el principio de reciprocidad.

La solución acerca de este tema que, aún en la actualidad, continúa siendo una cuestión polémica en la doctrina, la encontramos en la respuesta del Abogado General en sus conclusiones a una cuestión prejudicial planteada al Tribunal de Justicia de la Unión Europea (en adelante, TJUE) en el asunto C-303/05 cuando, ante la postura doctrinal que considera a la orden europea de detención y entrega una especie del género extradición, pone de manifiesto en su conclusión número 39 que, entre ambas instituciones, existen relevantes diferencias, tanto desde el punto de vista legislativo y doctrinal, como jurisprudencial. Continúa afirmando, además, en su conclusión número 40, que "cuando la atención se dirige al resultado, florecen las coincidencias, pero las disparidades

92 Nosotros hemos puesto de manifiesto en diversas ocasiones que consideramos que, a pesar de estar ante instrumentos que persiguen el mismo fin y los mismos objetivos, nos encontramos ante instrumentos de cooperación diferentes Vid. FONTESTAD PORTALÉS, L., "La orden europea de detención y entrega: origen y principios rectores", en Justicia: revista de derecho procesal, núm. 1-2, 2011, pp. 239-244 y "El procedimiento de transmisión de la orden europea de detención y entrega en la nueva ley de reconocimiento mutuo de resoluciones penales en la Unión Europea", en Reflexiones jurídicas sobre cuestiones actuales, Ed. Aranzadi, Madrid 2017, pp. 389-426. En esta misma línea SÁNCHEZ LEGIDO cuando afirma que "La orden europea de detención y entrega representa el instrumento pionero y más simbólico de la filosofía con la que, desde la Unión Europea, trata de darse respuesta desde mediados de la década de los noventa a las crecientes demandas de seguridad". Cfr. SÁNCHEZ LEGIDO, A., "La euro-orden, el principio de doble incriminación y la garantía de los Derechos fundamentales”, op.cit., pág. 53. 
descuellan si se repara en los fundamentos de este modo de colaboración y en la forma en la que se desarrolla" ${ }^{93}$.

En segundo lugar, admitiendo que el sistema de entrega europeo entrara en el concepto amplio de extradición habría que preguntarse cómo se llevaría a cabo el control del cumplimiento del principio de reciprocidad teniendo en cuenta que, como vimos anteriormente, el mismo recae en el Gobierno y, precisamente, la euroorden se caracteriza por su naturaleza jurisdiccional sin intervención posible del Gobierno en la decisión de la posible entrega de la persona reclamada ${ }^{94}$. Este obstáculo se salvaría reconociendo la posibilidad de los órganos jurisdiccionales no de comprobar si, efectivamente, en la práctica, el Estado de emisión cumple la condición de la reciprocidad, sino de realizar un control acerca de si la legislación del Estado de emisión permite dicha reciprocidad. En el primer caso, tal y como afirma DE LA QUADRA-SALCEDO JANINI, nos encontramos ante un control político de la reciprocidad mientras que, en el segundo caso, se trataría de una apreciación jurídica de la misma que se basa en una interpretación de las normas jurídicas del Estado de la autoridad de emisión ${ }^{95}$.

93 Conclusiones del Abogado General, Dámaso Ruiz-Jarabo Colomer, a la cuestión prejudicial planteada al TJUE en el asunto C-303/05, de 12 de septiembre de 2006, disponible en la página web del Tribunal de Justicia de la Unión Europea (http://curia.europa.eu/juris/showPdf.jsf?text=pri ncipio $\% 2$ Bde $\% 2$ Breciprocidad $\% 2$ By $\% 2$ Borden $\% 2$ Beuropea $\% 2$ Bdetenc $\mathrm{i} \% 25 \mathrm{C} 3 \% 25 \mathrm{~B} 3 \mathrm{n} \&$ docid $=63884 \&$ pageIndex $=0 \&$ doclang $=$ es $\&$ mode $=r e$ $\mathrm{q} \& \operatorname{dir}=\& \mathrm{occ}=$ first \&part=1\&cid=6860222). Última revisión, junio 2020.

94 Efectivamente, es el Gobierno el que cuenta con los medios necesarios para acceder al cumplimiento de la reciprocidad por parte de los demás Estados, análisis que difícilmente podrá llevar a cabo la autoridad judicial de ejecución. En este sentido, Vid. ROVIRA VIÑAS, A., Extradición y Derechos Fundamentales, Ed. Civitas, Madrid 2005, pág. 195.

95 En este sentido este autor considera más adecuado que la obligación de exigir la reciprocidad para proceder a la entrega no solo recaiga sobre el Gobierno, sino sobre todos los poderes públicos que participen en el procedimiento de extradición. De este modo, el órgano jurisdiccional competente como miembro integrante del poder judicial, sería perfectamente 
Precisamente, en relación con esta sentencia del TC, que niega la exigencia del principio de reciprocidad en el procedimiento de la euroorden, este mismo autor ${ }^{96}$ realiza una concluyente crítica y se manifiesta a favor de la vigencia del principio de la reciprocidad en la orden europea de detención y entrega por varias razones:

En primer lugar, porque considera que la orden europea de detención y entrega, lejos de ser un nuevo sistema de entrega en el que el principio de reciprocidad pierde la tradicional relevancia en el ámbito de la cooperación judicial penal internacional, es un nuevo instrumento de "entrega extradicional directa entre autoridades judiciales" pero que, en modo alguno, supone una superación del sistema de la extradición sometida a la exigencia constitucional de la reciprocidad.

En segundo lugar, considera este autor que no se puede dejar de lado la intención del constituyente de 1978 cuando regula principio constitucional de la reciprocidad en el artículo 13.3 CE. En este sentido, afirma que el espíritu de la norma llevaría a reconocer que la intención del legislador fue exigir el cumplimiento de la reciprocidad en los procedimientos de entrega de personas entre Estados soberanos para su persecución criminal ${ }^{97} \mathrm{y}$, dado que el sistema de la

competente para llevar a cabo el control del cumplimiento de la reciprocidad. DE LA QUADRA-SALCEDO JANINI, T., "La orden europea de detención y entrega y el principio constitucional de reciprocidad", op.cit, pp. 13-14. En relación con la posible denegación de una orden europea de detención por ausencia de reciprocidad Vid. CEZÓN GONZÁLEZ, C., Derecho extradicional, Ed. Dykinson, Madrid 2003, pág. 65.

96 Vid. la relevante crítica que de la STC 177/2006 realiza DE LA QUADRA-SALCEDO JANINI, T., "El encaje constitucional del nuevo sistema europeo de detención y entrega", op.cit., pp. 283-285.

97 Aunque también reconoce la posibilidad de que el legislador bien hubiera podido referirse, en el artículo $13.3 \mathrm{CE}$, a una extradición caracterizada, en otras, por la intervención de la autoridad gubernativa, en cuyo caso, lógicamente, la orden europea de detención y entrega no respondería al concepto de extradición ni en sentido amplio. Cfr. DE LA QUADRA-SALCEDO JANINI, T., "La orden europea de detención y entrega y el principio constitucional de reciprocidad”, op.cit., pág. 12. 
orden europea de detención y entrega, no ha perdido dicha nota de soberanía estatal, el principio de reciprocidad resulta aplicable "... por mucho espacio europeo de libertad, seguridad y justicia que se quiera promover en el marco del Tercer Pilar". En contra de esta afirmación, sin embargo, se muestra el Abogado General del TJUE en sus conclusiones al citado asunto C-303/05 $5^{98}$.

Por último, y en tercer lugar, continúa su crítica a la STC, advirtiendo que el legislador español no puede renunciar en la ley de transposición de la citada Decisión Marco que regula la euroorden al principio constitucional de la reciprocidad extradicional.

Si tenemos en cuenta esta relevante crítica a la decisión del TC y partimos de la posibilidad constitucional de exigir el cumplimiento de la reciprocidad por parte de la autoridad judicial de ejecución en el sistema de entrega europeo, o euroorden, lo siguiente que nos deberíamos plantear es si, en un sistema basado en los principios del reconocimiento mutuo y la confianza entre Estados ${ }^{99}$, que suponen

98 42. "En la extradición entran en contacto dos Estados soberanos, el requirente y el requerido, que actúan desde posiciones autónomas: uno ruega la colaboración del otro, que decide si la presta caso por caso, en atención a motivos que trascienden el universo estrictamente jurídico, para adentrarse en el ámbito de las relaciones internacionales, donde el principio de oportunidad ostenta un papel relevante. Por esta razón la intervención última de responsables politicos y criterios como el de reciprocidad o el de doble incriminación se justifican por provenir de esferas diferentes".

43. "El escenario exhibe otro decorado cuando el auxilio se reclama y se proporciona en el seno de un sistema jurídico supranacional de integración, en el que los Estados, renunciando parcialmente a su soberanía, transfieren competencias a instancias ajenas, con capacidad de producción normativa. Esta aproximación, propia del primer pilar de la Unión, opera también en el tercero, intergubernamental pero con una evidente vocación "comunitaria», como lo ha demostrado la sentencia Pupino, 36 trasladando a las decisiones marco categorías del primer pilar y alguno de los parámetros característicos de las directivas".

99 No podemos olvidar que, en el Consejo de Tampere, el principio de reconocimiento mutuo se convierte en la "piedra angular" de la cooperación 
la base de la creación de un espacio de libertad, seguridad y justicia ${ }^{100}$, efectivamente, y en consonancia con el espíritu de este nuevo instrumento de cooperación judicial, se ha suprimido este principio clásico de la extradición en que consiste la reciprocidad.

Atendiendo a lo concluido por el Abogado General en sus, reiteradamente citadas conclusiones a la cuestión prejudicial planteada al TJUE en el asunto C-303/05 pero que no podemos dejar de mencionar de nuevo, no cabe duda alguna de la ausencia de reciprocidad en la orden europea de detención y entrega, pues así lo pone de manifiesto expresamente en su conclusión número 45.

Ahora bien, tras una detenida lectura del régimen de denegación de una orden europea de detención y entrega previsto tanto en la Decisión Marco de la $\mathrm{UE}^{101}$, como en la ley española de transposición ${ }^{102}$ llegamos a la conclusión

judicial civil y penal. Vid. Considerando número 33 del Consejo de Tampere (Finlandia) sobre la creación de un espacio de libertad, seguridad y justicia en la Unión Europea celebrado durante los días 15 y 16 de octubre de 1999 cuyas conclusiones se pueden consultar en www.europa. eu.int. Para un análisis detallado de las directrices políticas y objetivos del Consejo Europeo de Tampere de 1999 Vid. FERNÁNDEZ ROZAS, J.C., "El espacio de libertad, seguridad y justicia consolidado por la constitución europea", Diario La Ley núm. 6097, de 30 de septiembre de 2004, pp. 6-7.

100 Vid. Considerandos número 6 y 10, respectivamente, de la DM. En este sentido Vid. Sentencia del Tribunal de Justicia (Gran Sala) de 27 de mayo de 2019 (Asuntos acumulados C-508/18 y C-82/19 PPU) en la que "El Tribunal de Justicia recuerda, para empezar, que la orden de detención europea es la primera concreción en el ámbito del Derecho penal del principio de reconocimiento mutuo, que se basa a su vez en el principio de confianza recíproca entre los Estados miembros. Estos dos principios tienen una importancia fundamental, dado que permiten la creación y el mantenimiento de un espacio sin fronteras...” (ECLI: ECLI:EU:C:2019:456). Vide. también los artículos 3.1 TUE y 4.2 j TFUE.

101 Artículos 3 y 4.

102 Ley 23/2014, de 20 de noviembre, de reconocimiento mutuo de resoluciones penales en la Unión Europea. 
de que, en este sistema de entrega europeo, el principio de reciprocidad ha desaparecido, pero solo de forma aparente. Y ello es así porque el órgano jurisdiccional de ejecución ante la existencia de motivos de denegación facultativos podrá o, si consideramos que el mandato constitucional recae no solo sobre la extradición, sino también sobre la euroorden, deberá decidir sobre la entrega de la persona reclamada atendiendo al principio de reciprocidad. Esto significa, por tanto, que aquellas causas de denegación de la entrega previstas en la ley española con carácter facultativo pero que, en el Estado de emisión, se regulan como motivos imperativos de denegación, provocarían que el juez español, como autoridad judicial de ejecución, tuviera que denegar la entrega en aplicación del principio de reciprocidad ${ }^{103}$.

Como de todos es sabido, la Decisión Marco que regula la euroorden prevé una serie de causas o motivos de denegación de la entrega por parte de la autoridad judicial de ejecución que son, unos de carácter imperativo y, por tanto, así deben ser previstos en las leyes internas de cada Estado miembro, y otros de carácter facultativo ${ }^{104}$. En este último supuesto, los Estados miembros tienen libertad para regularlos o no entre los motivos de denegación de la entrega en sus respectivos ordenamientos jurídicos y, a su vez, tienen la posibilidad de regularlos como motivos de denegación, bien de carácter imperativo, bien de carácter facultativo para

103 En esta línea Vid. LÓPEZ ORTEGA, J.J., "El futuro de la extradición en Europa”, op.cit., pág. 310.

104 Para un análisis exhaustivo sobre esta materia Vid. DE HOYOS SANCHO, M., "Euroorden y causas de denegación de la entrega", Cooperación judicial penal en la Unión Europea: La orden de detención europea de detención y entrega, Ed. Lex Nova, Valladolid 2005, pág. 264 y "Eficacia transnacional del non bis in idem y denegación de la euroorden", Diario La Ley núm. 6330, de 30 de septiembre de 2005, pp. 4-5. Sobre la entrega condicionada en el sistema europeo de entrega Vid. GONZÁLEZ CANO, M.I., "La ejecución condicionada del mandamiento de detención y entrega europeo", Unión Europea Aranzadi, Vol. 30, Nº 6, 2003, págs. 5-15. 
que sea, en este último supuesto, en cada caso concreto, el órgano jurisdiccional como autoridad judicial de ejecución el que decida, facultativamente, aplicarlo o no para proceder a la entrega de la persona reclamada ${ }^{105}$. En este caso es cuando la doctrina se muestra a favor de que la autoridad judicial de ejecución, a la hora de decidir si aplica o no el motivo facultativo de denegación, lo debe hacer en atención al principio de reciprocidad pues, como afirma DE LA QUADRA-SALCEDO JANINI, "Precisamente la Ley española al mantener como facultativos tales motivos "implanta" con naturalidad en la Ley 3/2003 la aplicación del principio de reciprocidad" 106 .

105 En el caso de la entrega de nacionales, por ejemplo, el Informe de la Comisión basado en el artículo 34 de la Decisión Marco del Consejo, de 13 de junio de 2002, relativa a la Orden de detención europea y a los procedimientos de entrega entre Estados miembros denunció la práctica de algunas autoridades judiciales que deniegan la entrega de sus nacionales alegando su competencia y, sin embargo, no llevan a cabo su enjuiciamiento; otros Estados exigen la reciprocidad y la conversión de la pena impuesta a sus nacionales y otros exigen para sus nacionales el principio de doble incriminación y condiciona su entrega a la conversión de su pena (Bruselas, 23 de febrero de 2005 COM (2005) 63 final).

106 Referencia que hoy debemos entender referida a la LRM. Vid. DE LA QUADRA-SALCEDO JANINI, T., "La orden europea de detención y entrega y el principio constitucional de reciprocidad", op.cit., pág. 16. Por su parte, el acuerdo entre la Unión Europea y Noruega e Islandia sobre el procedimiento de entrega exige, para la eliminación del control de la doble incriminación respecto del listado de los treinta y dos delitos previstos en el artículo 2.2 de la DM sobre la orden europea de detención y entrega, que tanto Noruega e Islandia, como la Unión Europea en representación de cada uno de sus Estados miembros, declaren previamente dicha eliminación está sujeta al régimen de reciprocidad. Vid. artículo 3.4 del Acuerdo (DOUE L 292, de 21 de octubre de 2006). En cuanto a la relación entre el principio de la doble incriminación y el principio de reciprocidad, BAUTISTA SAMANIEGO, afirma que la reciprocidad se exige con posterioridad, tras el control de la doble incriminación. Vid. BAUTISTA SAMANIEGO, C., Aproximación crítica a la orden europea de detención y entrega, Ed. Comares, Granada 2015, pág 54. 
En este sentido, CALAZA LÓPEZ afirma que “... en la regulación del objeto del procedimiento de emisión y ejecución de la orden europea, subyace el clásico criterio de la «reciprocidad»..." aunque advirtiendo expresamente que dicho principio de reciprocidad resultará aplicable en relación con la interpretación y aplicación de una norma pero, en ningún caso, como sí ocurre en el proceso de extradición, como consecuencia de la ausencia de normativa interna "... estando en juego el principio de la legalidad, de la «diplomacia judicial»" $" 107$.

Hasta aquí, si defendiéramos la exigencia del principio de reciprocidad en el procedimiento de la orden europea de detención y entrega, el único problema que podríamos encontrar sería el de tener que reconocer que, una vez más, y a pesar de que el legislador europeo se vanaglorie de haber erradicado de la orden europea de detención y entrega los principios que tradicionalmente rigen en el proceso de extradición, la Decisión Marco no ha conseguido suprimir el principio de reciprocidad que continúa aplicándose, aunque de manera indirecta, en el sistema europeo de detención y entrega.

Más problemas podríamos encontrar para defender esta idea en el hecho de que la autoridad judicial de ejecución denegara una orden europea como consecuencia del cumplimiento del principio de reciprocidad por algún motivo de denegación no previsto en la Decisión Marco que regula la euroorden, pero sí en el Estado de emisión ${ }^{108}$. En

107 Cfr. CALAZA LÓPEZ, S., "El procedimiento de ejecución de la «euroorden»", op. cit., pp. 357 y 358.

108 Posibilidad que los Estados justifican en atención a lo previsto en el Considerando número 12 de la DM según el cual "La presente Decisión marco respeta los derechos fundamentales y observa los principios reconocidos en el artículo 6 del Tratado de la Unión Europea y reflejados en la Carta de los derechos fundamentales de la Unión Europea, en particular en su capítulo VI. Nada de lo dispuesto en la presente Decisión marco podrá interpretarse en el sentido de que impide la entrega de 
estos supuestos, en el caso de España, si partimos de la obligación constitucional de la exigencia de la reciprocidad, nos veríamos en la tesitura bien de incumplir el mandato constitucional y proceder a la entrega sin cumplir con la reciprocidad para, así, cumplir con la normativa europea o bien, al contrario, en cumplimiento de la exigencia constitucional de la reciprocidad, denegar la entrega incumpliendo el Derecho Europeo.

En este sentido el TJUE, en reiterada jurisprudencia, se muestra contundente cuando afirma que los Estados miembros no deben someter la entrega al requisito de la reciprocidad $^{109} \mathrm{y}$, en caso de incumplimiento por parte del Estado de emisión de la norma europea, el Estado de ejecución debe denunciar el incumplimiento del Derecho europeo por parte de aquel ante el TJUE ${ }^{110}$.

una persona contra la que se ha dictado una orden de detención europea cuando existan razones objetivas para suponer que dicha orden de detención europea ha sido dictada con fines de persecución o sanción a una persona por razón de sexo, raza, religión, origen étnico, nacionalidad, lengua, opiniones políticas u orientación sexual, o que la situación de dicha persona pueda quedar perjudicada por cualquiera de estas razones. La presente Decisión marco no impedirá a ningún Estado miembro aplicar sus normas constitucionales relativas al respeto del derecho a un proceso equitativo, la libertad de asociación, libertad de prensa y libertad de expresión en los demás medios."

109 Vid. STJUE, de 29 de enero de 2013, Asunto Radu, C-396/11 (ECLI:EU:C:2013:39); STJCE de 30 de septiembre de 2003, Asunto Colegio de Oficiales de la Marina Mercante española, C-405/01 (ECLI:EU:C:2003:515) y de 30 de junio de 2005, Asunto Tod`s SpA, Tod`s France SARL y Heyraud SA, C-28/04 (ECLI:EU:C:2005:418).

110 Vid. El Artículo 19.3 TUE atribuye competencia al TJUE para resolver los recursos por un Estado miembro (Tratado de la Unión Europea 7 DOUE C 83, de 30 de marzo de 2010) y los artículos 259 y 260 TFUE que regulan el procedimiento por incumplimiento ante la Comisión y el TJUE, respectivamente (Tratado de la Unión Europea y del Tratado de Funcionamiento de la Unión Europea. DOUE núm. 202, de 7 de junio de 2016). Sobre la insatisfacción de los efectos de las propias sentencias del TJUE reconociendo el incumpliendo de la normativa europea de un Estado miembro puesto que, entre otras razones, no supondría el 
Como consecuencia de todo lo expuesto hasta este momento la conclusión a la que llegamos es que, aún cuando la DM que regula la orden europea de detención y entrega no hace alusión alguna al principio de reciprocidad en este nuevo sistema de entrega en el ámbito de la Unión Europea, tampoco está prohibiendo a los Estados miembros que la incluyan en sus respectivas leyes internas de transposición de la misma. Ello, sin duda, acarrea múltiples problemas en cuya base se encontraría la falta de armonización ${ }^{111}$ entre los diferentes procedimientos de entrega previstos en cada Estado miembro que, a su vez, dependerá de la regulación normativa del principio de reciprocidad en sus respectivos ordenamientos jurídicos ${ }^{112}$.

En España, como hemos podido comprobar, la cuestión no es baladí pues partimos de una previsión normativa de carácter constitucional aunque referida exclusivamente para el procedimiento de la extradición. Por lo tanto, aun cuando ni siquiera la propia ley española de transposición de la DM prevea la aplicación de la reciprocidad a la hora de decidir sobre la entrega de la persona reclamada, siempre y cuando consideremos que este sistema de entrega europeo tiene la consideración, en sentido de amplio, de extradición, la autoridad judicial de ejecución española tendrá que

cumplimiento de la exigencia de reciprocidad por parte del Estado denunciado Vid. DE LA QUADRA-SALCEDO JANINI, T., "La orden europea de detención y entrega y el principio constitucional de reciprocidad”, op.cit., pág. 18.

111 Vid. Informe de la Comisión basado en el artículo 34 de la Decisión Marco del Consejo, de 13 de junio de 2002, relativa a la Orden de detención europea y a los procedimientos de entrega entre Estados miembros (Bruselas, 23 de febrero de 2005 COM (2005) 63 final).

112 Sobre los problemas que plantea la diferente regulación de las causas de denegación de una orden europea de detención y entrega previstas en la DM con carácter facultativo se puede consultar la obra de FONTESTAD PORTALÉS, L., "Ejecución de la orden europea de detención y entrega en juicios celebrados sin comparecencia del imputado", en Nueve estudios para informar un proceso penal europeo y un Código Modelo para potenciar la cooperación jurisdiccional iberoamericana. ROBLES GARZÓN, J. A., (dir.), Ed. Aranzadi, Pamplona 2013, pp. 41-73. 
comprobar, dentro de sus posibilidades, eso sí, que el Estado de emisión cumple con el principio de reciprocidad.

No son pocas las voces que en nuestra doctrina se manifiestan en contra de la aplicación de este principio en el sistema de la eurorden, llegando incluso a proponer una reforma constituciona $1^{113}$. Sin embargo, quizás, la solución menos complicada para evitar las posibles denegaciones de órdenes europeas de detención y entrega en España alegando como causa de denegación la ausencia de reciprocidad, sería reconocer que la orden europea de detención y entrega es una institución diferente e independiente de la extradición independientemente, insistimos, de que ambas compartan un mismo fin y objetivo pues, como afirma el Abogado General (Sr. Dámaso Ruiz-Jarabo Colomer) en sus, ya citadas conclusiones, "ahí acaban las similitudes" $" 114$.

Desde nuestro modesto punto de vista, no cabe duda alguna que nos encontramos ante procedimientos distintos que no comparten lo más importante: su naturaleza jurídi$\mathrm{ca}^{115}$. Por lo tanto, nos atrevemos a poner de manifiesto que

113 Vid. GARCÍA SÁNCHEZ. B., "Dificultades de la euroorden ante su puesta en práctica por los tribunales nacionales de la Unión Europea”, en Anuario de derecho penal y ciencias penales, Tomo 60, Fasc/mes 1, 2007, pág. 368. En contra también de la aplicación de la reciprocidad en el procedimiento de la orden europea de detención y entrega Vid. GONZÁLEZ RIVAS, J., y ALCÁCER GUIRAO, R., "Extradición y euroorden como formas de cooperación internacional. Doctrina constitucional", en Encuentro trilateral de los Tribunales Constitucionales de Italia, Portugal y España, Lisboa noviembre de 2012, disponible en https://www.tribunalconstitucional.es/es/trilateral/documentosreuniones/36/ponencia $\% 20$ espa $\%$ C3\%91a\%202012.pdf, pág. 15). Ultima revisión, junio 2020.

114 Vid. Conclusión número 42 del Abogado General en las ya citadas conclusiones al asunto C-303/05, pág. 3650.

115 Así se desprende del contenido del artículo 1.1 DM cuando define la orden europea de detención y entrega: "La orden de detención europea es una resolución judicial dictada por un Estado miembro con vistas a la detención y la entrega por otro Estado miembro de una persona buscada para el ejercicio de acciones penales o para la ejecución de una pena o una medida de seguridad privativas de libertad". Asimismo, JIMENO BULNES, 
la problemática aplicación de la reciprocidad en el procedimiento de la euroorden, atendiendo a lo previsto en el artículo 13.3 CE, desaparece con el reconocimiento de la euroorden como instrumento autónomo y diferente a la extradición ${ }^{116} \mathrm{o}$, en su defecto, partiendo de un concepto estricto de la extradición donde no tuviera cabida el sistema europeo de entrega.

En esta línea y, aún cuando el TC no ha establecido una doctrina jurisprudencial al respecto ${ }^{117}$, si es cierto que, en la conocida y ya citada anteriormente STC 177/2006, de 5 de junio, afirma que el sistema europeo de detención y entrega es un sistema distinto al de la extradición y, en consecuencia, no operan los mismos principios ${ }^{118}$.

en su momento, dio la bienvenida a la orden europea de detención y entrega reconociendo que no solo suponía una reforma de carácter formal o terminológica, sino también procesal y conceptual. $C f r$. JIMENO BULNES, M., "La orden europea de detención y entrega: Aspectos procesales", Diario La Ley núm. 5979, de 19 de marzo de 2004, pág. 5.

116 A favor FONSECA MORILLO, F., "La orden de detención y entrega europea”, en Revista de Derecho Comunitario Europeo núm. 14, eneroabril 2003, pág. 70 .

117 El propio TC en relación con la aplicación del principio de reciprocidad en la extradición en lo que a la protección de derechos fundamentales se refiere ha puesto de manifiesto que no entra en el ámbito de su competencia el control de las decisiones judiciales sobre esa cuestión, excepto en aquellos supuestos en los que se pueda advertir arbitrariedad en su aplicación puesto que, en estos casos, existiría ante una vulneración del derecho a la tutela judicial efectiva. Es por ello por lo que, como afirma el TC, "no ha conformado una doctrina acerca del principio de reciprocidad plasmado en el art. 13.3 CE-dado su limitado ámbito de competencia en materia de legalidad extradicional, circunscrito al canon del art. 24.1 $C E$ ". Cfr. Fundamento Jurídico núm. 7 de la, ya citada, STC 30/2006, de 30 de enero (ECLI:ES:TC:2006:30). Un análisis acerca del ámbito de aplicación del principio de reciprocidad en el procedimiento de la extradición y en la orden europea de detención y entrega, lo podemos encontrar en PÉREZ MANZANO, M., "El control constitucional de la extradición y la orden europea de detención y entrega”, op.cit., pp. 302305 y 314-315, respectivamente.

118 En contra, DE LA QUADRA-SALCEDO JANINI para quien solo existe "un mero cambio de nombre". Cfr. DE LA QUADRA-SALCEDO JANINI, T., "El encaje constitucional del nuevo sistema europeo de detención y entrega”, op.cit., pág. 254. 


\section{Bibliografía}

ARANGÜENA FANEGO, C., "La orden europea de detención y entrega. Análisis de las Leyes 2 y 3 de 14 de marzo de 2003, de transposición al ordenamiento jurídico español de la Decisión Marco sobre la «euroorden»", Revista de Derecho Penal (Lex Nova), núm. 10, 2003.

ARNÁIZ SERRANO, A., "Evolución de la Cooperación Judicial Penal Internacional: en especial, la Cooperación Judicial Penal en Europa”, Consejo General del Poder Judicial, $5^{\text {a }}$ edición, 2013, pág. 35 (disponible en http://www5.poderjudicial.es/cvep12-13/CVCP1301-ES.pdf).

AA.VV., "Una propuesta de Ley de cooperación jurídica internacional en materia civil", Boletín del Ministerio de Justicia, Año LXVI, núm. 2143, junio 2012.

BACHMAIER WINTER L., "La cooperación judicial en asuntos penales en Europa: consideraciones prácticas, situación actual y propuestas de futuro", en El derecho procesal español del siglo $X X$ a golpe de tango, Ed. Tirant lo blanch, Valencia 2012.

BAUTISTA SAMANIEGO, C., Aproximación crítica a la orden europea de detención y entrega, Ed. Comares, Granada 2015.

BENAVIDES CASALS, M.A., "Reservas en el ámbito del Derecho Internacional de los Derechos Humanos", Ius et Praxis, Vol. 13, núm. 1, 2007. https://doi. org/10.4067/s0718-00122007000100007

BUENO ARÚS, F., "El principio de reciprocidad en la extradición y la Legislación española", en Anuario de derecho penal y ciencias penales, Tomo 37, 1984.

BUENO ARÚS, F. y DE MIGUEL ZARAGOZA, J., Manual de Derecho Penal Internacional, Universidad Pontificia de Comillas, Madrid 2003.

BUENO JIMÉNEZ, M., "Hacia una cooperación judicial en la Unión Europea: el reconocimiento mutuo de 
resoluciones judiciales en el ámbito penal”, disponible en http://noticias.juridicas.com/conocimiento/ articulos-doctrinales/11954-hacia-una-cooperacionjudicial-en-la-union-europea:-el-reconocimiento-mutuo-de-resoluciones-judiciales-en-el-ambito-penal/.

CALAZA LÓPEZ, S., "El procedimiento de ejecución de la «euroorden»", en Boletín de la Facultad de Derecho de la UNED, núm. 26, 2005.

CARRILlO SALCEDO, J.A., Soberanía del Estado y Derecho Internacional, Ed. Tecnos, Madrid 1969. https:// doi.org/10.1093/iclqaj/19.1.179

CEZÓN GONZÁlEZ, C., Derecho extradicional, Ed. Dykinson, Madrid 2003.

CONDE-PUMPIDO TOURÓN, C., "La orden de detención europea", Actas del I Congreso Internacional. El espacio Judicial Europeo, celebrado en Toledo del 29 al 31 de octubre de 2003

CUERDA RIEZU, A., "La extradición y la Orden Europea de Detención y Entrega", en Revista CENIPEC núm. 25, Vol I, Enero-Diciembre 2006.

DE LA QUADRA-SALCEDO JANINI, T., "El encaje constitucional del nuevo sistema europeo de detención y entrega", Revista Española de Derecho Constitucional, núm. 78, septiembre-diciembre, 2006.

DE LA QUADRA-SALCEDO JANINI, T., "La orden europea de detención y entrega y el principio constitucional de reciprocidad", en Revista española de derecho europeo, núm. 18, 2006 (versión electrónica, disponible en BIB 2006/806).

DE MIGUEL ZARAGOZA, J., "Algunas consideraciones sobre la extradición", disponible en Boletín del Ministerio de Justicia, núm. 1738.

DE MIGUEL ZARAGOZA, J., "Algunas consideraciones sobre la Decisión Marco relativa a la orden de detención europea y a los procedimientos de entrega en la perspectiva de la extradición”, Actualidad Penal, 
2003-1, marginales 140-141 (núm. 4, del 20 al 26 de enero de 2003).

DONDÉ MATUTE, J., "Extradición y Derechos Humanos", en Extradición y debido proceso, Ed. INACIPE, México 2017. https://doi.org/10.25100/hye.v15i52.8275

FALCON Y TELLA, M. J., "La equity angloamericana", en Foro, Nueva época, núm. 1/2005.

FERNÁNDEZ ROZAS, J. C., "El espacio de libertad, seguridad y justicia consolidado por la constitución europea", Diario La Ley, núm. 6097, de 30 de septiembre de 2004.

FERRERE COMELLAS, V., y MIERES MIERES, L.J., "Algunas consideraciones acerca del principio de legalidad penal", en Revista española de Derecho Constitucional, núm. 55, 1993.

FONSECA MORILLO, F., "La orden de detención y entrega europea", en Revista de Derecho Comunitario Europeo núm. 14, enero-abril 2003.

FONT I SEGURA, A., "Artículo 3. principio general favorable de cooperación", Comentarios a la ley de cooperación jurídica internacional en materia civil, MÉNDEZ GONZÁLEZ, F.P., y PALAO MORENO, G., (dirs.), Ed. Tirant lo Blanch, Valencia 2017. https:// doi.org/10.17103/redi.70.1.2018.4.12

FONTESTAD PORTALÉS, L., "El procedimiento de transmisión de la orden europea de detención y entrega en la nueva ley de reconocimiento mutuo de resoluciones penales en la Unión Europea", en Reflexiones jurídicas sobre cuestiones actuales, Ed. Aranzadi, Madrid 2017, pp. 389-426.

FONTESTAD PORTALÉS, L., "Ejecución de la orden europea de detención y entrega en juicios celebrados sin comparecencia del imputado", en Nueve estudios para informar un proceso penal europeo y un Código Modelo para potenciar la cooperación jurisdiccional iberoamericana. Robles Garzón (dir.), Ed. Aranzadi, Pamplona 2013. 
FONTESTAD PORTALÉS, L., "La orden europea de detención y entrega: origen y principios rectores", en Justicia: revista de derecho procesal, núm. 1-2, 2011.

GARCÍA SÁNCHEZ, B., "Dificultades de la euroorden ante su puesta en práctica por los tribunales nacionales de la Unión Europea”, en Anuario de derecho penal $y$ ciencias penales, Tomo 60, Fasc/mes 1, 2007.

GÓMEZ CAMPELO, E., "Orden de detención europea y garantías procesales", en Justicia versus seguridad en el espacio judicial europeo, Ed. Tirant lo blanch, Valencia 2011.

GONZÁLEZ CANO, M. I., "La ejecución condicionada del mandamiento de detención y entrega europeo", Unión Europea Aranzadi, Vol. 30, № 6, 2003, págs. 5-15.

GONZÁLEZ RIVAS, J., y ALCÁCER GUIRAO, R., "Extradición y euroorden como formas de cooperación internacional. Doctrina constitucional", en Encuentro trilateral de los Tribunales Constitucionales de Italia, Portugal y España, Lisboa, noviembre de 2012, disponible en https://www.tribunalconstitucional.es/ es/trilateral/documentosreuniones/36/ponencia $\% 20$ espa $\% \mathrm{C} 3 \% 91 \mathrm{a} \% 202012$.pdf.

GONZÁLEZ-CUELLAR SERRANO, N., "La "Euroorden": hacia una Europa de los carceleros", en Diario La Ley, núm. 6619, 2006.

GONZÁLEZ-CUELLAR SERRANO, N., "Las euroórdenes emitidas por el tribunal supremo de España", Revista Teoría y Título: Derecho. Revista de pensamiento jurídico, núm. 26/2019.

GUISADO LITTERIO, T.M., "La extradición fuera de un marco convencional: la operación de los principios de reciprocidad y solidaridad internacionales", en Estándares internacionales de protección de derechos humanos aplicables al instituto de extradición, S. González Napolitano (dir.), SGN Editora, Buenos Aires 2018. 
GUZMAN, A., How international law works: Introduction. International Theory, 1(2), 2009. https://doi. org/10.1017/s1752971909990042

GUZMÁN ZAPATER, M., "Artículo 14. Motivos de denegación", Comentarios a la ley de cooperación jurídica internacional en materia civil, MÉNDEZ GONZÁLEZ, F.P., y PALAO MORENO, G., (dirs.), Ed. Tirant lo Blanch, Valencia 2017.

HERCÉ QUEMADA, V., y GÓMEZ ORBANEJA, E., Derecho Procesal Penal, $10^{\mathrm{a}}$ edición, Madrid 1987.

IVO MALVEZZI, M., "Reconocimiento de sentencias Extranjeras: Los procedimientos del derecho interno italiano y español", en Anales de derecho, Universidad de Murcia, Número 23, 2005.

JIMENO BULNES, M., "La orden europea de detención y entrega: Aspectos procesales", Diario La Ley, núm. 5979, de 19 de marzo de 2004.

LOPEZ ORTEGA, J.J., "El futuro de la extradición en Europa", en Apéndice a la obra de CEZÓN GONZÁLEZ, C., Derecho extradicional, Ed. Dykinson, Madrid 2003.

NIETO MARTÍN, A., "Introducción", en Código de Derecho penal europeo e internacional, Arroyo Zapatero, L., y Nieto Martín, A., (dirs.), Ministerio de JusticiaUCLM, 2008.

PAN MONTOJO, F., "Estudio de la reciprocidad en la doctrina, legislación y jurisprudencia", en Revista Española de Derecho Internacional (REDI), núm. 9 (1-2), 1956.

PASTOR RIDRUEJO, J.A., Curso de Derecho Internacional Público y Organizaciones internacionales, Ed. Tecnos, $23^{\text {a }}$ edición, Madrid 2019.

PASTRANA BUELVAS, E., "El principio de la no-reciprocidad: entre el deber ser y su regulación jurídica en el marco de las relaciones económicas internacionales y de cooperación”, en Papel Político, núm. 17, junio de 2005. 
PÉREZ CEBADERA, M.A., La nueva extradición europea: la orden de detención y entrega, Ed. Tirant lo Blanch, Valencia 2008.

PÉREZ MANZANO, M., "El control constitucional de la extradición y la orden europea de detención y entrega”, en Comentarios a la Constitución Española, M. Pérez Manzano e I. Borrajo Iniesta (Coords), Ed. Wolters Kluwer, Madrid 2018.

PLANTEY A., Tratado de Derecho Diplomático. Teoría y práctica, (trad. de la $2^{\mathrm{a}}$ edición francesa por IGLESIAS SANZ A.), Madrid 1992.

RODRÍGUEZ BENOT, A., "La ley de cooperación jurídica internacional en materia civil", Cuadernos de Derecho Transnacional (Marzo 2016), Vol. 8, núm 1.

ROVIRA VIÑAS, A., Extradición y Derechos Fundamentales, Ed. Civitas, Madrid 2005.

SÁNCHEZ LEGIDO, A., "La euro-orden, el principio de doble incriminación y la garantía de los Derechos fundamentales", en Revista electrónica de estudios internacionales (REEI), núm. 14 (2007).

TRÍAS Y GIRÓ, J., Estudios de Derecho Internacional Privado, con aplicación especial al Derecho español, Sociedad General de Publicaciones, Barcelona 1921.

VELAZQUEZ ELIZARRARAS, J. C., "Reflexiones generales en torno a la importancia de los principios del derecho internacional", Anuario Mexicano de Derecho Internacional (online), Volumen 12, Año 2012, pp. 407-453. Disponible en http:// www.scielo.org.mx/scielo.php?script=sci_arttex t\&pid=S1870-46542012000100012. https://doi. org/10.22201/iij.24487872e.2012.12.403 